\title{
Um passeio pela literatura paranaense
}

\author{
Ana Crhistina Vanali ${ }^{1}$
}

- Enviado em 28/05/2016

- Aprovado em 18/06/2016

\section{RESUMO}

Este trabalho pretende apontar os diferentes autores que marcaram a literatura paranaense. É um trabalho de caráter incompleto e absolutamente exploratório, pelo fato de apenas apontar os escritores paranaenses e não tratar dos debates e temas colocados em questão pelos mesmos. Pode se considerar esse trabalho uma espécie de incursão em um terreno desconhecido. Incursão essa marcada pelo fato de ao ser questionada sobre a literatura paranaense não se ter muito a responder na época. Apesar de possuir uma literatura muito criticada pela falta de identificação das obras produzidas com o território e a cultura paranaense, o Paraná é reconhecido por ter revelado grandes autores para o cenário da literatura nacional. Apresentamos alguns dos nomes mais consagrados da literatura paranaense, reconhecidos não apenas por seus leitores, mas também pela crítica e por grandes escritores.

Palavras-chave: Literatura paranaense. Correntes literárias. Literatura e política.

\section{INTRODUÇÃO}

Existe uma literatura que identifique o Paraná? Bento Munhoz da Rocha Neto, como querendo eternizar um episódio, reproduziu em livro o que a revista carioca “A Ordem” escreveu:

O Paraná é um Estado típico desses que não têm um traço que faça dele alguma coisa notável, nem geograficamente como a Amazônia, nem pitorescamente como a Bahia ou o Rio Grande do Sul. Sem uma linha vigorosa de história como São Paulo, Minas e Pernambuco, sem uma natureza característica como o Nordeste, sem lendas de primitivismo como o Mato Grosso e Goiás". Por isso o Paraná "forma essa retaguarda característica de incaracterísticos". E mais adiante: "O paranaense não existe"! E conclui categórico, o articulista: "O Paraná é um Estado sem relevo humano”. (Rocha Netto, 1969)

Então Bento revidou:

Bendizemos a plebe que floresce ao suor fecundante do semeador a criar riquezas. E temos os lances generosos do gaúcho. A galhardia cativante de suas atitudes francas. A linha correta das condutas elegantes. A coragem de encarar de peito descoberto as situações precárias. E de vencê-las de cabeça ao sol. (Rocha Netto, 1969)

\footnotetext{
${ }^{1}$ Doutoranda em Sociologia na UFPR. Endereço eletrônico: anacvanali@yahoo.com.br
} 
Mas nossos escritores se valem deste paranaense, escrevendo em sua defesa, valorizando-o e identificando-o em suas narrativas? Quem são os escritores “paranistas”?

1) Paulo Leminski tem uma temática de estilo próprio. Espalhafatoso, identifica a si mesmo e não a sua terra, nem em prosa e nem em versos;

2) Helena Kolody é uma poetisa da língua portuguesa e, por incluir - vez ou outra - a palavra "pinheiro" em suas estâncias, não é identificadora do paranismo;

3) Dalton Trevisan se identifica como o "Vampiro de Curitiba" por não apresentar, em sua temática, uma referência de identidade, tão diversa é sua estética;

4) Domingos Pellegrini, também, variando a temática entre o urbano e o micro-regional, pouca contribuição tem dado para a afirmação de uma literatura identificadora do Paraná.

5) Noel Nascimento ${ }^{2}$, autor de "Casa Verde", pode ser considerado "paranista" por romancear a historiografia do Paraná. Descreve tipos de uma época e numa área geográfica difícil de uniformizar as gentes, pois os conflitos do "Contestado" se deram nos limites do campeiro com o matuto. Por seu esforço deve fazer parte da galeria dos literatos paranistas.

6) Adolpho Mariano da $\operatorname{Costa}^{3}$, notadamente com três de suas obras "O Donatário", "Canal de Desvio" e "Parábolas da Terra sem Males", contribui para registrar, mesmo que pouco, o tipo do homem das micro-regiões Oeste e Sudoeste do Estado do Paraná.

\footnotetext{
${ }^{2}$ Noel Nascimento (Ponta Grossa, 2 de novembro de 1925 - Curitiba, 23 de junho de 2013). Filho de Sebastião Nascimento e Maria Claudia Bittencourt de Castro Nascimento. Formou-se em Direito e foi promotor de justiça em várias cidades do interior do Paraná. Colaborou durante décadas em jornais e revistas com ensaios, poemas e textos literários. Publicou A Justiça e o fim da Repressão, Casa Verde (1963), Coreto de Papel, Cosmonave, A Nova Estética, A Escola Humanista, Arcabuzes (1995), A Revolução do Brasil (2005), A Nova Civilização (2005), Contos Fantásticos (2005). Foi atingido pelo Ato Institucional $\mathrm{n}^{\circ}$ 1, preso político em 64 e em 75, retornando ao Ministério Público na vigência da Lei da Anistia. Tomou posse da cadeira 27 da Academia Paranaense de Letras (APL) em 23 de maio de 1979. Em 1995 ganhou o Concurso Nacional de Romances promovido pela Secretaria de Estado da Cultura do Paraná com "Arcabuzes".
}

${ }^{3}$ Adolpho Mariano da Costa (Carmo do Parnaíba/MG, 7 de março de 1936 - Curitiba, 29 de março de 2014). Advogado formado pela USP. Obteve o prêmio Fundação Teatro Guaíra, para Leitura Dramática da peça Canal de Desvio, melhor texto paranaense de 1987 que, após encenação, foi apresentada em Porto Alegre, Curitiba e outras cidades. O texto "Um Índio é um Índio" foi transcrito nos Anais da Assembléia Legislativa do Paraná, em 1982. Autor de contos, crônicas, narrativas, poemas, romances, ensaios e peças teatrais. Textos em vídeos, matérias jornalísticas, além de participações em várias coletâneas. Obras publicadas: O Donatário (contos, 1979); Iara Acalanto em Bronze Perene (1993); Parábolas da Terra Sem Males (narrativas, 2000); Solução de Conflitos no Âmbito do Mercosul (1995); Mergulho no Mar de Minas (romance, 2004). 
Ninguém duvida quando lê Graciliano Ramos, José Lins do Rego ou João Cabral de Melo Neto, que sejam nordestinos. A obra de Monteiro Lobato também é regional (de São Paulo e metade sul de Minas Gerais), porque em seus personagens não figuram os gaúchos, os nordestinos, os amazonenses, e nem os tropeiros e os pantaneiros. A literatura regional gaúcha é identificada de sopetão, porque, como disse Mário de Andrade: "De todas as literaturas regionais do Brasil, tenho a impressão que a gaúcha é a que mais apresenta uma identidade de princípios, uma normalidade geral dentro do bom, uma consciência de cultura, uma igualdade intelectual e psicológica, que a torna fortemente unida e louvável”. A Bahia se identifica em Jorge Amado assim como Jorge Amado identifica a Bahia, na sua escrita.

Esse texto é um brevíssimo estudo sobre a história da literatura no Paraná, desde suas origens e formação até a produção literária contemporânea. Iniciaremos com a instalação da Província do Paraná, no ano de 1853, mas sem dúvida houve produção literária na época em que o Paraná ainda era a $5^{\circ}$ Comarca de São Paulo, mas até agora não há nenhum trabalho para conhecermos qual é a voz mais longínqua da literatura paranaense. O objetivo é contribuir para ampliar a consciência do público leitor sobre a literatura feita no Paraná, apontando os principais nomes como uma sugestão de orientação.

\section{ORIGENS DA LITERATURA PARANAENSE: ROMANTISMO NO PARANÁ: da instalação da Província (1853) até a Proclamação da República (1889)}

O escritor paranaense mais antigo seria Fernando Amaro de Miranda (1831-1857), que nascido por volta de 1831, em Paranaguá, sobreviveu quatro anos à data da instalação da Província do Paraná, em 1853. Seus escritos começam a aparecer em 1854 nas páginas do jornal Dezenove de Dezembro, primeiro jornal da província recém-criada.

Fernando Amaro, considerado o primeiro poeta paranaense, era da corrente romântica, devido a época em que existiu. A pequena canção que vem a seguir, composta quase às vésperas da morte nos demonstra isso.

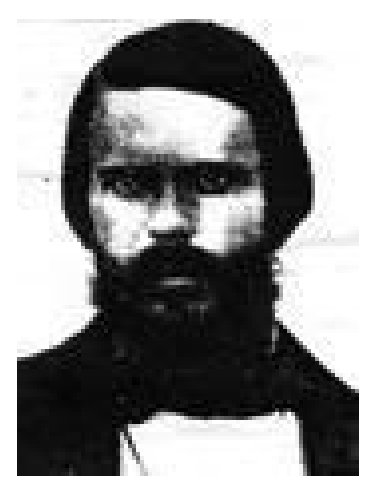

Fernando Amaro (fonte: http://christianbarbosa.blogspot.pt. Acesso 05.10.2014) 
Outra voz desse primeiro momento da literatura paranaense, nascida em Paranaguá, é Júlia Maria da Costa (1844-1911) que tinha 13 anos quando Fernando Amaro faleceu. Ao contrário de Fernando Amaro que teve uma morte prematura, Júlia da Costa acompanhou o gradativo desenvolvimento da província até muito longe, pois só faleceu em 1911, com 67 anos de idade. Os dois livros que publicou, Flores Dispersas e Bouquê de Violetas, são respectivamente de 1867 e 1868. Mas suas produções aparecem em revistas e jornais paranaenses até o fim de sua vida, e dela há uma coleção de cartas de amor consideradas de uma expressividade surpreendente ${ }^{4}$.

O triste destino de Júlia da Costa, de esposa repudiada e humilhada em face da amante do marido mantida sob o mesmo teto, pôs-lhe na alma uma nota de amargura trágica. Daí a fuga espiritual de que resultaram as cartas que afirmam admiráveis e de poemas como esse abaixo:

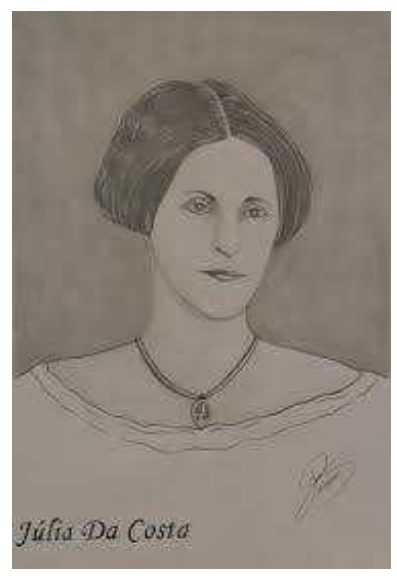

Júlia da Costa (fonte: Instituto Histórico e Geográfico de Paranaguá)

Podemos citar como autores desse primeiro momento:

- João Batista Ribeiro (1838-1884)

- Antonio Martins de Araújo (1845-1894) - autor de Vozes Campestres

- Terésio Porto (1849-1888)

- Teófilo Soares Gomes (1854-1935)

Todos são autores românticos, até o fundador da literatura dramática no Paraná Teófilo Soares Gomes, nascido em Santa Catarina, mas tendo vivido uma longa vida em terra paranaense, já em 1884 submetia ao julgamento do Conservatório Dramático Brasileiro, no Rio de Janeiro seu drama Milagres de Nossa Senhora do Pilar, no qual reconheceu originalidade e vocação para o gênero o Barão de

\footnotetext{
${ }^{4}$ Para mais detalhes consultar MUZART, Zahid Lupinacci. Anuário de Literatura. SP: Companhia de Letras, 1987.
} 
Paranapiacaba ${ }^{5}$. Outra peça de Teófilo Soares Gomes, Gererê ou o Quilombo do Sargento, drama em quatro atos, submetido igualmente ao juízo daquele conservatório alcançou consagração brasileira. A vida política roubou à grande arte o melhor das atividades do dramaturgo que, no entanto, ainda produziu outras peças.

Os nomes citados até agora constituem o grupo dos precursores na literatura paranaense, cuja história completou 160 anos no último dia 19 de dezembro de 2013.

A primeira geração literária propriamente dita, apontada pelo literato Rodrigo Júnior ${ }^{6}$ como gloriosa compreende os seguintes nomes, ainda da tradição romântica dos precursores:

- Antonio Ribeiro de Macedo (1843- ????): foi um estudioso de problemas sociais, geográficos e históricos.

- José Morais (1849-1909): foi poeta, cronista e humorista. Publicou em 1874 o livro Sempre Vivas, em que aparecem sonetos parnasianos. Um dos mestres das gerações posteriores.

- Luís Ferreira França (1853-1921): deixou larga produção dispersa em revistas e jornais.

- Antonio de Camargo Pinto (1856-1883): considerado o "Castro Alves paranaense", não deixou livro. Era abolicionista. Pela voz de Antonio de Camargo Pinto assim fala a liberdade:

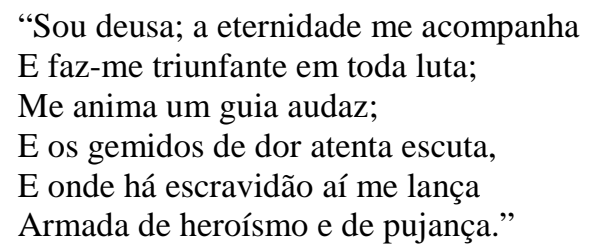

- Joaquim Serapião do Nascimento (1847-1911): nasceu em Iguape, município do litoral sul de São Paulo. Era jovem quando veio residir no Paraná, e logo deixou a sua marca, tornando-se conhecido como emérito

\footnotetext{
5 João Cardoso de Meneses e Sousa, Barão de Paranapiacaba (Santos, 25 de abril de 1827 - Rio de Janeiro, 2 de fevereiro de 1915) foi um poeta, jornalista, advogado, tradutor, professor e político brasileiro. Filho de João Cardoso de Meneses e Sousa, formou-se em 1848 pela Faculdade de Direito de São Paulo, residiu alguns anos em Taubaté, onde foi professor de História e Geografia. Depois exerceu advocacia no Rio de Janeiro, até 1857. Então entrou para a repartição geral da fazenda, onde exerceu diversas funções no Rio, São Paulo e Pernambuco. Em 1862, foi incumbido, com José de Alencar, de elaborar o plano de criação do Teatro Nacional. Chegou a censor teatral e presidiu o Conservatório Dramático, quando Machado de Assis era um dos seus censores, em 1871. Foi deputado por Goiás, de 1873 a 1876. Estreou na literatura aos 17 anos, com o "Cântico do Tupi". Publicou seu primeiro livro em 1849, a "Harpa Gemedora", coleção de poesias. Também publicou um opúsculo, "O Christianismo", em São Paulo. Traduziu, verso por verso, o "Oscar d'Alva", poema de Lord Byron, em 1857. Também é tradutor de "Fábulas de La Fontaine", em 1886. Colaborou com os jornais Correio Mercantil e Jornal do Commercio, além da revista Tribuna Catholica redigida pelo cônego J.C. Fernandes Pinheiro. Recebeu, por Decreto Imperial de 8 de maio de 1883, o título de Barão de Paranapiacaba. Fonte: MENEZES, Raimundo de. Dicionário literário brasileiro - $2^{\mathrm{a}}$ edição. Rio de Janeiro: Livros Técnicos e Científicos, 1978.

6 João Baptista Carvalho de Oliveira (conhecido como Rodrigo Junior) foi jornalista, poeta e escritor. Nasceu em Curitiba, 10/09/1887 - e faleceu em Curitiba, 08/06/1964). Mais detalhes consultar: http://www.millarch.org/artigo/dois-ensaios-lembrando-quem-foi-rodrigo-junior. Acesso em 17 de janeiro de 2014.
} 
educador. Ficou consagrado no campo da poesia, prosador e teatrólogo fecundo, compôs diversas peças, tendo-se extraviado os originais de muitos trabalhos. Algumas obras publicadas: José do Egito; $O$ nascimento de Jesus; O filho pródigo; A vítima do jogo; e O Senhor Aprígio em apuros, ou a carta que dá dinheiro. Quando da inauguração da ponte provisória sobre o Rio Iguaçu em Porto União da Vitória em 26 de novembro de 1906, Joaquim Serapião declamou o seguinte poema:

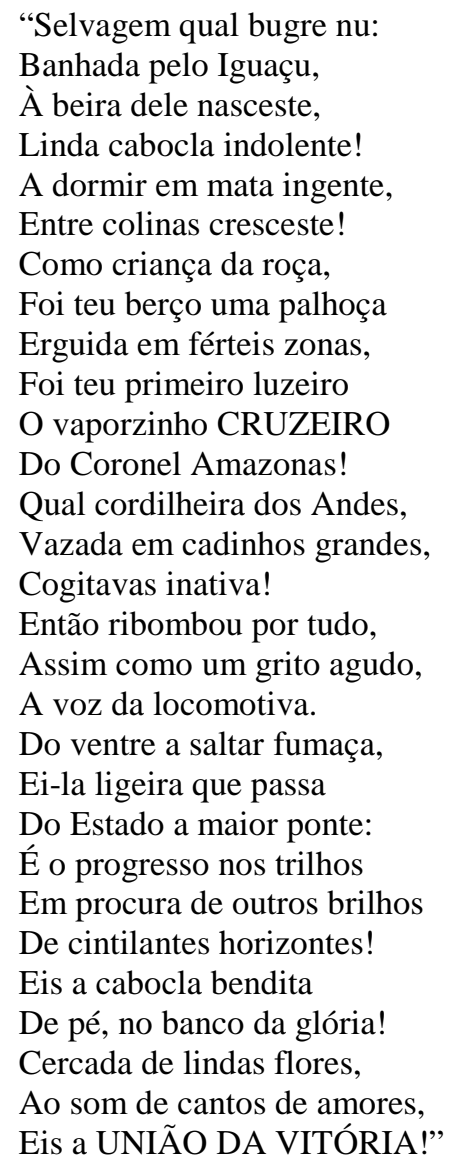

- Gabriel Pereira (1851-1901): nasceu no Rio Grande do Sul, mas exerceu forte ação de presença no Paraná. Publicou em Curitiba Sertanejas (1881), na linha lírica romântica.

- Albino José da Silva (1850-1905): nasceu em Paranaguá em 19 de janeiro de 1850. Faleceu em Ponta Grossa, em 24 de junho de 1905. Seria tudo na vida, incluindo político, negociante, comissário de polícia, professor, fazendeiro, administrador das capatazias do Porto de Paranaguá, jornalista, fundador de diversos periódicos, deputado estadual, abolicionista, republicano, poeta, delegado literário do ensino, prefeito municipal em São Pedro de Itararé, onde fundou o Clube de Leitura, educador e libertador de escravos. Teve uma infância cheia de dificuldades e, órfão de pai com apenas cinco anos de idade, passou a residir na casa de um tio. Logo que pôde, abandonou a casa de seu tutor, deixando o litoral e alcançando o planalto curitibano em busca de novos horizontes. Em companhia de João Carvalho de Oliveira, dedicou-se ao comércio, seduzindo os clientes a tocar viola ante um círculo de admiradores, daí advindo o apelido de 
Albino Viola. Mesmo sem ter frequentado a escola, revelou-se poeta e, depois, jornalista, fundando seis jornais pelas cidades por onde passou: O Escolar e O Guaíra, em Campo Largo; O Diabinho, em Curitiba; Pátria Livre e Leitura Popular, em Paranaguá e Ponta Grossa. Publicou um único livro de poesias, Flores Campesinas, alguns folhetos e contos. Casado com a campo-larguense Rosinha, teve nove filhos. Cinco deles, Niepce, Zeno, Aldo, Ciro e Alda participaram da fundação do Centro de Letras do Paraná. Entregou-se à tarefa de lutar contra a escravidão chegando, muitas vezes, a ocultar em sua residência os escravos que fugiam do cativeiro, sofrendo por esse gesto perseguições políticas. Certamente um dos mais entusiastas propagandistas do regime republicano no Paraná, fundando, em Paranaguá, o Clube Republicano e o jornal Pátria Livre, este com excelentes colaboradores, como Leôncio Correia e Emiliano Pernetta.

- José Francisco Rocha Pombo (1857-1933): se tornou um dos maiores historiadores do Brasil. De 1881 a 1886 publicou uma série de poesia, romance, conto e ensaio ainda na linha romântica, inclusive o poema épico em doze cantos A Guaíra. Em seguida integrou-se como poeta no Movimento Simbolista.

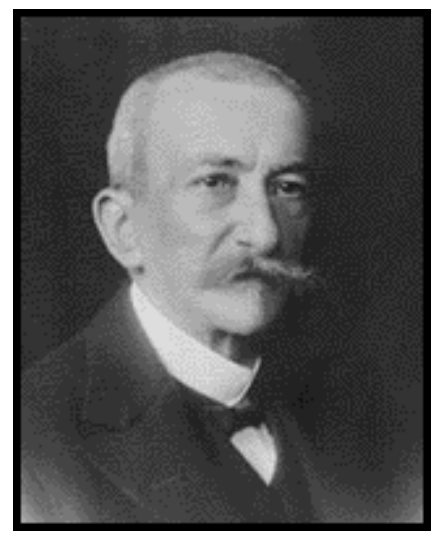

Rocha Pombo (fonte: site Academia Brasileira de Letras)

Lúcio Leocádio Pereira (1860-1933): é autor da obra Contos Paranaenses e Folhetins (1896) e fundador da Revista Espírita (1890). É um dos sócios fundadores do Instituto Histórico e Geográfico Paranaense. 


\section{ORIGENS DO SIMBOLISMO: NATURALISMO ${ }^{7}$ - PARNASIANISMO ${ }^{8}$ : durante a Primeira República (1889-1930)}

Uma segunda fase da literatura paranaense abriu-se, com maior audácia e mais profundidade e corresponde ao largo período denominado naturalista-parnasiano-simbolista da literatura nacional.

Acrescentando aos nomes que já estavam na lida literária, aparecem:

- Leôncio Correia (1865-1950): considerado o patriarca da literatura paranaense. Poeta, jornalista, crítico, tentou também o teatro, sendo dos nomes que mais fortemente repercutiram fora do Paraná. Seus livros de poemas Flores Agrestes e Volatas (1887), Litanias (1900), Em derredor da vida (1917) são marcados por um suave lirismo, para-parnasiano por seus versos trabalhados e estruturas firmes, mas sem a rigidez plástica do Parnaso. Suas peças de teatro constam do drama Talento e Ouro (1883) e das comédias Manhã de Amor, $O$ batizado do nenê e $O$ minueto.

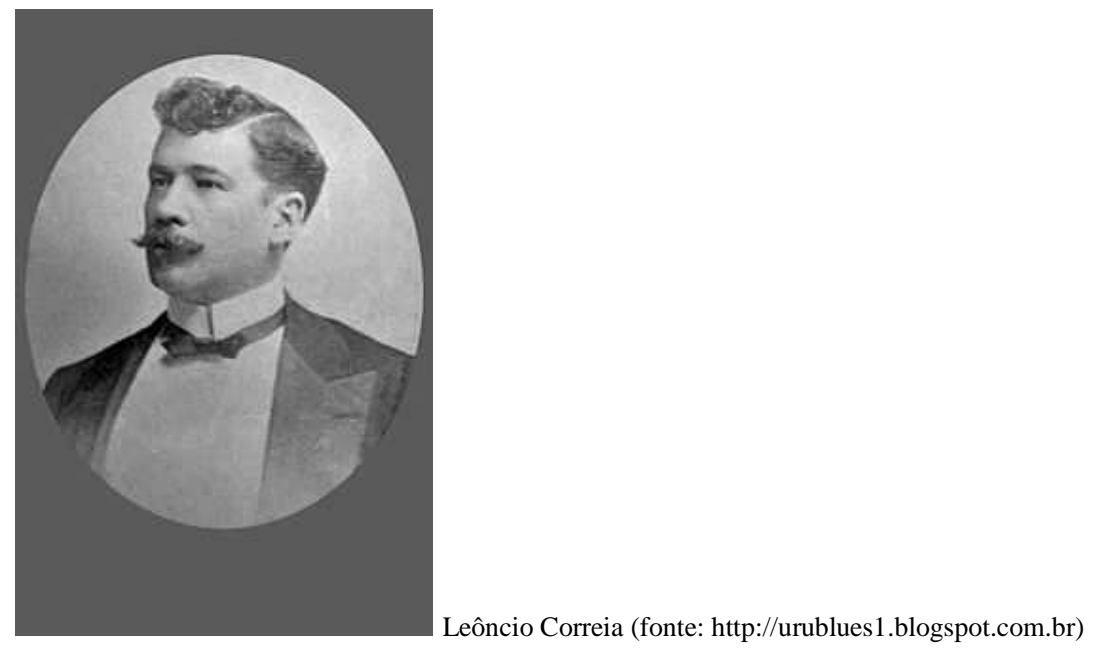

- Emilio Correia de Menezes (1867-1918): teve a projeção mais forte, dentro e fora do estado do Paraná pelo impressionante acento de seus poemas, marcados por uma estranha fusão de parnasianismo e simbolismo e por sua irreprimível veia satírica. Pertenceu a Academia Brasileira de Letras e publicou entre outros Marcha fúnebre (sonetos de 1892); Poemas da morte (1901); Dies Irae (poemeto de 1906); Últimas rimas (1917); Os deuses em ceroulas (versos satíricos de 1924).

\footnotetext{
${ }^{7}$ NATURALISMO: Caracterizou-se pela construção de enredo e personagens submetidas a um determinismo cego do ambiente e das leis naturais.

${ }^{8}$ PARNASIANISMO: A escola adota uma linguagem mais trabalhada, empregando palavras sofisticadas e incomuns, dispostas na construção de frases, atendendo às necessidades da métrica e ritmo regulares, que dificultam a compreensão, mas que lhes são característicos.
} 


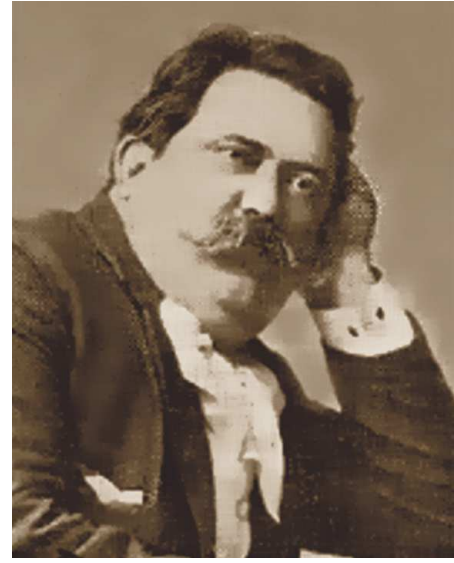

Emílio de Memezes (fonte: www.poesiaspoemaseversos.com.br)

- Dias da Rocha Filho (1862-1895): seus poemas só foram publicados em um único livro Poesias (1916). É considerado o mestre parnasiano no Paraná. Foi tradutor dos poemas do Lord Byron (Parasina e Ponte de Abidos).

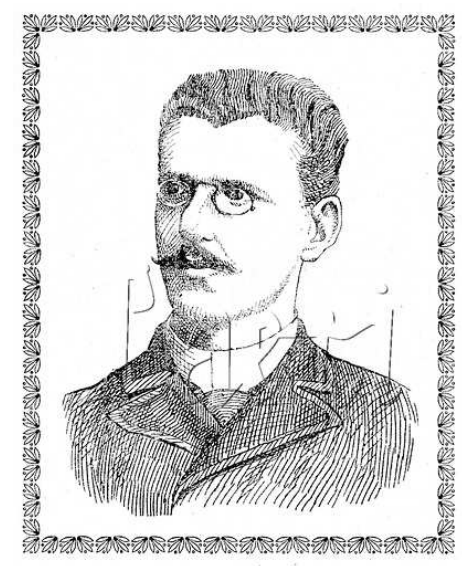

Joaquim DIAS DA ROCHA Filho

(fonte: www.poesiaspoemaseversos.com.br)

- Domingos Nascimento (1863-1915): publicista, jornalista, poeta e contista, marchou, como poeta de um post-romantismo para um parnasianismo temperado de simbolismo. Da primeira fase da sua produção ficaram Revoadas (1883) e Trenos e Arruídos (1887).

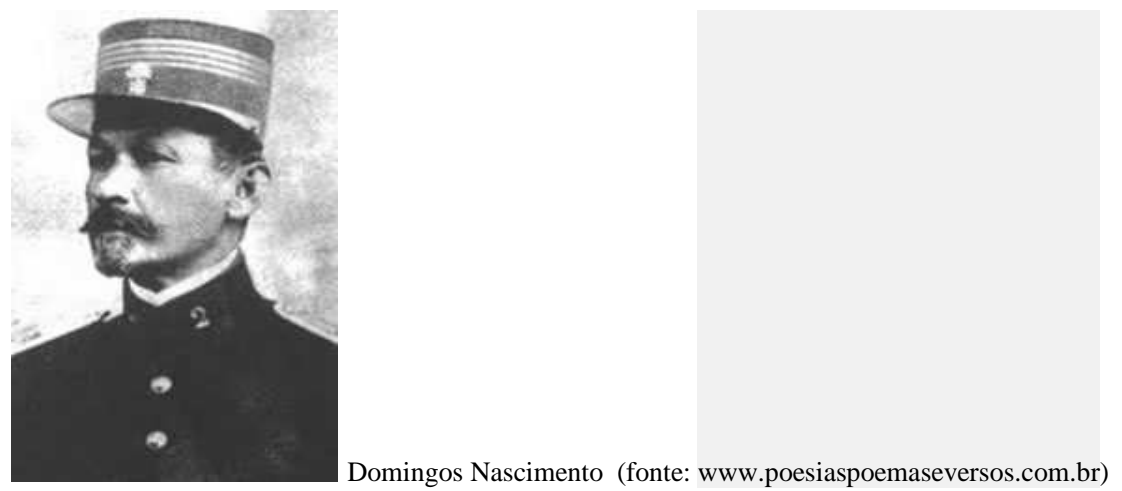


- Emiliano Perneta (1866-1921): um dos criadores da revista O Cenáculo. Poeta brasileiro importante, um dos fundadores do Simbolismo em nosso país. Emiliano era irmão de Júlio Perneta. Considerado o maior poeta paranaense em seu tempo, começou influenciado pelo parnasianismo. Foi abolicionista, tendo feito palestras em defesa dos ideais libertários. Publicou artigos políticos e literários, assim como passou a incentivar, em Curitiba, a leitura de Baudelaire. Em agosto de 1911 foi aclamado "príncipe dos poetas paranaenses" em uma festa no Passeio Público . Em 1913 publicou o libreto Papilio Innocentia, para a ópera do compositor suíço Léo Kessler, baseado no romance Inocência do Visconde de Taunay. Sua obra poética mais importante inclui Ilusão (1911), Pena de Talião (1914) e Setembro (1934). Em 19 de dezembro de 1912, participou da fundação do Centro de Letras do Paraná, sendo seu presidente de 1913 a 1918.

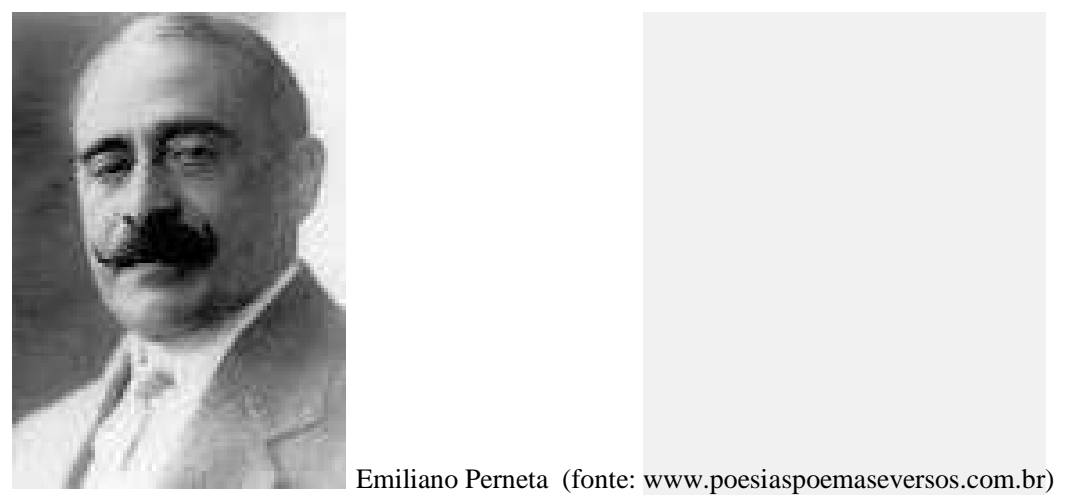

- Nestor Vitor (1868-1932): um dos criadores da revista O Cenáculo. Poeta, contista, ensaísta, romancista, crítico e conferencista. Foi amigo e estudioso da obra de Cruz e Sousa. Publicou deste as Obras Completas (1923-1924), com um exaustivo estudo da arte desse poeta. Autor de uma vasta obra, assim também um divulgador da literatura estrangeira, em particular a francesa.

Foi afastado desde muito moço do convívio com seus conterrâneos, pois viveu a maior parte da vida no Rio de Janeiro, salvo breve período que passou em Paris. Crítico e pensador (aliás é considerado o grande crítico do simbolismo brasileiro), realizou-se também como poeta, romancista e contista. Em Transfigurações (poemas), Amigos (romance), Signos (contos), deixou a prova de uma inspiração e de uma ideação poucos vulgares. Amigos, anterior à postulação definitiva das doutrinas freudianas, oferece traços da arte psicanalítica que posteriormente explorou no mundo.

No entanto, foram a crítica e o ensaísmo que lhe conferiram, entre os muitos da área literária, o título de mestre. Em face da crítica naturalista, Nestor Vitor assume um caráter novo no Brasil, pois desenvolve em profundidade sua crítica. Já no começo do século XX punha ele a 
inteligência brasileira em contato com as grandes correntes do espírito em plena vigência no Velho Mundo, através de ensaios sobre Ibsen, Barres, Edmond Rostand, Maeterlinck (no prefácio à tradução brasileira de A Sabedoria e o Destino), Nietzche, Novalis, etc., em trabalhos posteriormente incluídos no volume A Crítica de Ontem. Ainda hoje tais ensaios podem ser lidos com proveito máximo, pela força de penetração de sentidos essenciais que Nestor de Castro neles põe.

Também em profundidade foram trabalhados alguns de seus estudos sobre autores brasileiros como Cruz e Souza, Machado de Assis, Farias Brito, Rocha Pombo e Silveira Neto. Sua crítica compreendida nos livros Cartas à Gente e Os de Hoje, assume, por sua vez, caráter apostolar: no escritor que surgia, e no qual suas sutilíssimas antenas captavam sinais de valor positivo, procurava ele suscitar exatamente amor profundo à vocação revelada e fidelidade extrema ao próprio modo de ser.

Nestor Vitor ainda escreveu outros ensaios intitulados $O$ Elogio do Amigo e $O$ Elogio da Criança, assim como o livro Folhas que ficam e seu livro sobre Paris. Nos "elogios" o que aparece é um sábio à maneira de Sêneca, em serena contemplação do milagre humano. "Folhas que ficam" tem algo de um nietzscheanismo cristianizado em sua força de intuição surpreendente. Do volume sobre "Paris" e dos ensaios estrangeiros escreveu Silvio Romero que deviam ser traduzidos a outros idiomas para que fora do Brasil se percebesse a que ponto havia atingido a inteligência brasileira.

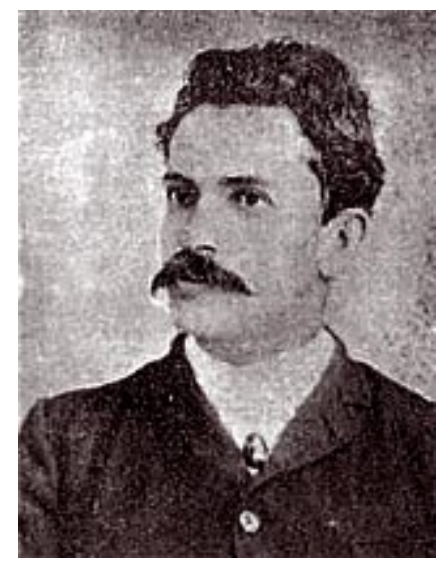

Nestor Vitor (fonte: www.poesiaspoemaseversos.com.br)

- Romário Martins (1874-1948): começou como auxiliar de tipografia e depois como redator. Na juventude demonstrou gosto pela história, e foi encarregado pelo governo paranaense de pesquisar arquivos sobre a história do Paraná em São Paulo. Em 1902 foi nomeado diretor do Museu Paranaense, cargo que ocupou durante 25 anos. Foi também diretor do Departamento de Agricultura do estado e deputado estadual em 1904. Para esse cargo foi reeleito mais sete vezes. Organizou congressos e fundou revistas literárias e 
científicas. Entre seus livros mais famosos estão: "Vozes intimas", "Noites Alvoradas", "O que é o Paraná", "Terra e gente do Paraná".

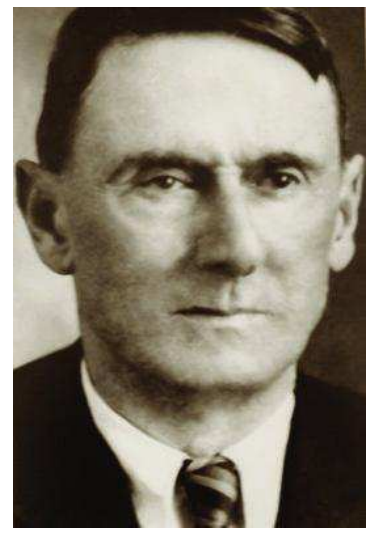

Romário Martins (fonte: www.poesiaspoemaseversos.com.br)

- Jayme Balão (1869-1930): foi professor, escritor, industrial, advogado, jornalista e político. Teve especial dedicação às letras, em uma relação diferente das matérias e crônicas do jornalismo. Em parceria com Augusto Stresser, ajudou a criar a primeira ópera paranaense como libretista de "Sidéria”. A ópera estreou, com grande sucesso, em Curitiba em 1912 . A obra de Stresser e Ballão foi destaque, nas semanas seguintes, em jornais e revistas de circulação nacional. Além desta ópera, escreveu peças teatrais, poemas e novelas e algumas de suas obras, são : Ceci (poemeto de 1896); Mártir (novela de 1897); Passionata (peça teatral de 1901); A Foz do Iguaçu e as Cataratas do Iguaçu e do Paraná (de 1921); As Cartas Falsas (de 1922); Elogio de Monteiro Tourinho (de 1928); O Ceguinho (novela de 1929). Jayme foi sócio fundador do Centro de Letras do Paraná e o seu presidente no ano de 1922.

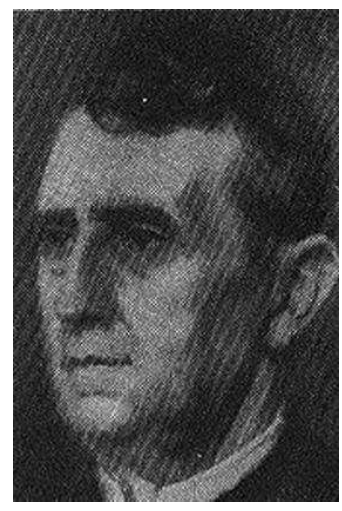

Jayme Ballão (fonte: www.poesiaspoemaseversos.com.br) 


\section{EVOLUÇÃO DO SIMBOLISMO?}

O aparecimento, em 1895 da revista O Cenáculo revestiu-se, na história da literatura paranaense, de importância transcendente. Coube a essa revista implantar o Movimento Simbolista no Paraná e concentrar o movimento simbolista brasileiro. Ficamos sabendo do profundo sentido do movimento, hoje considerado como expressivo de radical revolução do espírito em busca de sua perfeita autenticidade na poesia. E pela publicação Panorama do Movimento Simbolista Brasileiro, de Andrade Muricy, documentário exaustivo, ficamos sabendo da extensão total do movimento nacional e de seu influxo decisivo sobre o destino das letras paranaenses.

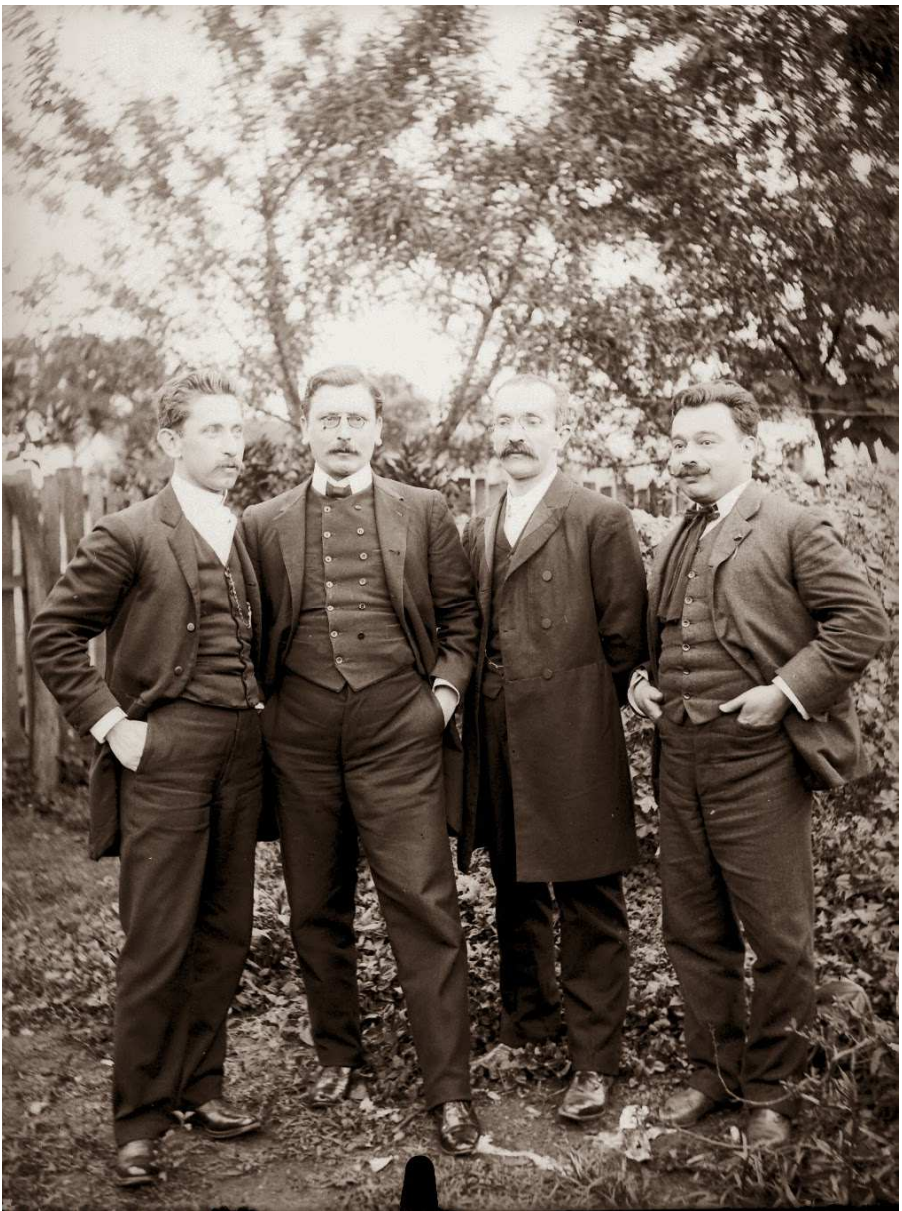

Os poetas do "Cenáculo": Dario Vellozo, Antônio Braga, Silveira Neto e Júlio Perneta. (créditos da foto: blog do Paulo José da Costa)

A constituição do grupo de O Cenáculo, que, aliás, atraiu e absorveu quase todos os valores ponderáveis do momento no Estado, como prendeu o interesse do país inteiro, ficou, por esta forma,

\footnotetext{
${ }^{9}$ SIMBOLISMO: estética que fez confluir uma apreensão subjetiva do mundo, com experiência mística do sagrado, relação com a natureza e busca pelo transcendental.
} 
significando muito mais do que simples acontecimento regional. Curitiba, até então uma capital simples, quase totalmente desprovida de recursos culturais, tornou-se um dos principais centros literários do Brasil.

O grupo, propriamente, compunha-se de quatro figuras, os diretores da revista:

$$
\text { 1. Dario Veloso (1869-1937) }
$$

2. Silveira Neto (1872-1942)

3. Júlio Perneta (1869-1921)

\section{Antonio Braga ${ }^{10}$ (1874- ????)}

O primeiro número de O Cenáculo saiu em abril de 1895. A causa imediata do surgimento da campanha literária inovadora no Paraná tinha sido a Revolução Federalista de 1893, que pusera sofrimento e inquietação nas almas, além do descobrimento maravilhado dos simbolistas da França e da Bélgica, propiciado pelos livros e notícias que trouxera, de retorno ao Brasil, em 1892, João Itiberê da Cunha $^{11}$, colega e amigo de Maeterlinck ${ }^{12}$ em Bruxelas.

Nesse primeiro número, contudo, em artigo de apresentação, proclama Dario Veloso que O Cenáculo não vinha pugnar dogmaticamente por nenhuma eschola philosophica ou litterária ... porquanto não admite o exclusivismo partidário, nem reza liturgicamente as litanias psalmodiadas pelo fanatismo orthodoxo

A lista de colaboradores era, de fato, eclética. Mas já aí figuravam Domingos Nascimento, Emiliano Perneta, João Itiberê, Rocha Pombo, Santa Rita que, com os do grupo de O Cenáculo, passaram a formar a falange pioneira da investida simbolista. E não obstante a declaração aludida, O Cenáculo se tornou o motor central do Movimento Simbolista, que daí por diante se estruturou em linhas definitivas.

\footnotetext{
${ }^{10}$ As referências biográficas a respeito de Antonio Braga são bastante escassas. Não encontrei vinculações do seu nome fora de referências ao grupo Cenáculo . Nasceu em Curitiba, em 1874. Colaborou com publicações locais, como a revista do Club Curitibano, O Futuro, Revista Azul, O Cenáculo. Desta última foi redator. Ver: O Cenáculo. FONTE: Revista do Club Curitibano. Coritiba, 15 de maio de 1895. Anno VI. N. ${ }^{\circ}$ 9: 5.

${ }^{11}$ João Itiberê da Cunha, também conhecido por Jean Itiberê (Cerro Azul, 8 de agosto de 1870 - Rio de Janeiro, 25 de fevereiro de 1953) foi um poeta, compositor, jornalista e crítico literário e musical. Era irmão do compositor e diplomata Brasílio Itiberê da Cunha. João introduziu, na literatura paranaense (com ênfase na poesia), as idéias simbolistas européias quando retornou da Bélgica, trazendo consigo referências de Maurice Maeterlinck, Albert Mockel e Iwan Gilkin. Em vida, publicou somente um livro e em francês: Preludes (1890).

${ }_{12}$ Maurice Polydore Marie Bernard Maeterlinck (Gante, 29 de agosto de 1862 — Nice, 5 de maio de 1949) foi um dramaturgo, poeta e ensaísta belga de língua francesa, e principal expoente do teatro simbolista.
} 
Tratemos agora das figuras pioneiras mais expressivas do Movimento Simbolista:

- Emiliano Perneta (1866-1921): de geração anterior à dos jovens diretores de O Cenáculo, publicara seus poemas de estréia sob o título de Músicas (1888), quando estudante em São Paulo, mas já se tornara, por ocasião do aparecimento da revista, nome dotado pela singularidade de suas maneiras. Só mais tarde, quando já em Curitiba, com o movimento em plena marcha, publicou $O$ Inimigo (prosa poemática, 1899); Alegoria (1903), Ilusão (1911) e Pena de Talião (tragicomédia em versos, 1914). E postumamente foram publicados Setembro (1934), Poesias Completas, dois volumes (1945) e Obras Completas (prosa, 1946).

Como em muitos dos simbolistas da França, da Bélgica, de Portugal, do Brasil, a inspiração inovadora marca o itinerário da poesia de coloridos satanistas, esdrúxula e inquieta, à La Baudelaire, para uma serena cantiga de tons cristãos: os derradeiros poemas de Emiliano Perneta, incluídos Setembro, são "orações" de humaníssimo sentimento e comovida expectação em face do mistério do ser e do destino. No meio do caminho, o que descobrimos é sobretudo um ímpeto heróico de fervor pela beleza, vivido em profundidade. Em seus mais belos poemas, Emiliano foi ardente intérprete da natureza paranaense, assim como Silveira Neto.

- Silveira Netto (1872-1942): em Luar de Inverno o autor ressalta as ruínas da solidão, da morte, do silêncio e do mistério. Sua refinada sensibilidade, alteada por um amargor metafísico, resultou em arte igualmente refinada, às vezes de extrema sutileza, sempre de originalidade flagrante - coisas de estranhar para quem era filho de operário, educado na tanoaria paterna, largou o formão e o martelo com que modelava aduelas para empunhar a pena de escritor.

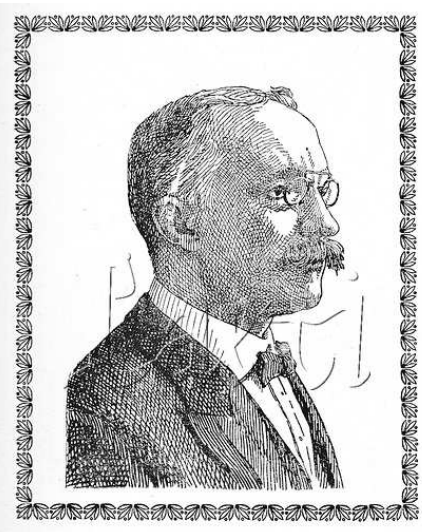

Manuel Azevedo da SILVEIRA NETTO

(fonte: www.poesiaspoemaseversos.com.br) 
Também Silveira Netto caminhou de uma poesia diferenciada para uma poesia humana. Os poemas Ronda Crespular, Fronde ao Sol e Margens do Nhundiaquara, rompem com a reclusão temperamental para atingir as marcas do universalismo.

Além dos livros mencionados acima, publicou Silveira Netto, que viveu até os 73 anos de idade, uma elegia a Antonio Nobre, um perfil espiritual de Cruz e Souza, um estudo sobre as Cachoeiras do Iguaçu, o poema-libreto $O$ Bandeirante, tendo deixado inéditos, além de Fronde ao Sol, um volume de crítica de arte e outro de estudos diversos.

- Dario Veloso (1869-1937): não era paranaense nato, mas viveu em Curitiba desde a adolescência. Constitui uma das mais importante figuras do simbolismo. Como poeta evocou misteriosos sentidos, da realidade ao amor, em estrofes carregadas de simbologia ocultista ou teosófica, ao mesmo tempo que, professor de história universal no Ginásio Paranaense, desenvolvia entre os alunos um apostolado pelo ressurgimento da beleza helênica. Ao fim, fundiu num só todas as doutrinas maçônicas, os príncipios da Revolução Francesa, do anticlericalismo, o pensamento de Pitágoras e um extremado civismo brasileiro e americano, organizando em Curitiba, o Instituto Neo Pitagórico $^{13}$. Exerceu vasta influência sobre as gerações sucessivas pelo fascínio de seu verbo e pelas ressureições helênicas das festas anuais da Primavera, as quais eram, de fato, realizações de poeta.

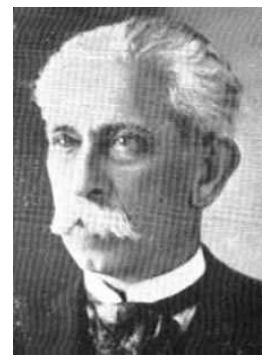

Dario Velloso (fonte: www.poesiaspoemaseversos.com.br)

\footnotetext{
${ }^{13}$ O Instituto Neo Pitagórico de Curitiba foi fundado em 26 de novembro de 1909. Seu lema era estudo-preserverançabondade. O fundador do instituto foi Dario Vellozo, pensador e escritor. Nasceu no Rio de Janeiro em 26 de novembro de 1869 e aos 14 anos foi morar em Curitiba, onde desenvolveu intensa atividade intelectual. Foi professor de História no Ginásio Paranaense, diretor e redator de revistas e jornais, entre os quais Ramo de Acácia, O Cenáculo, A Esphynge, Club Curitybano, O Electra e A República, que no final do século 19 e início do século 20 divulgavam a ousadia, a liberdade de pensamento e de concepção da arte. Em 1909, junto com um grupo de livres pensadores, composto por alunos e professores do Ginásio Paranaense, fundou em Curitiba o Instituto Neo Pitagórico. Esse Instituto, expressão social e jurídica do grupo neopitagórico, passou a sediar o Movimento Mundial do Pitagorismo. Em 1918, com a construção do Templo das Musas, também em Curitiba, fundamentou-se a estratégia social desse grupo no Paraná e no Brasil. O Instituto Neo Pitagórico promovia reuniões com finalidades de iniciação de novo membro, administrativas, musicais e literárias ou até mesmo em homenagem a personalidades ou povos, precedidas da leitura e comentário de trechos dos escritos de Pitágoras. Os irmãos neopitagóricos deificavam os gregos, mergulhavam na literatura e procuravam reconstruir o pensamento e o modo de viver dos antigos. Desejavam reprisar não somente as ideias, mas a arquitetura, o vestuário e até nomes pessoais. Em 1936, Dario Vellozo publicou o livro Jesus Pitagórico. Foi sua última publicação antes de falecer, em 28 de setembro de 1937, na cidade de Curitiba.
} 


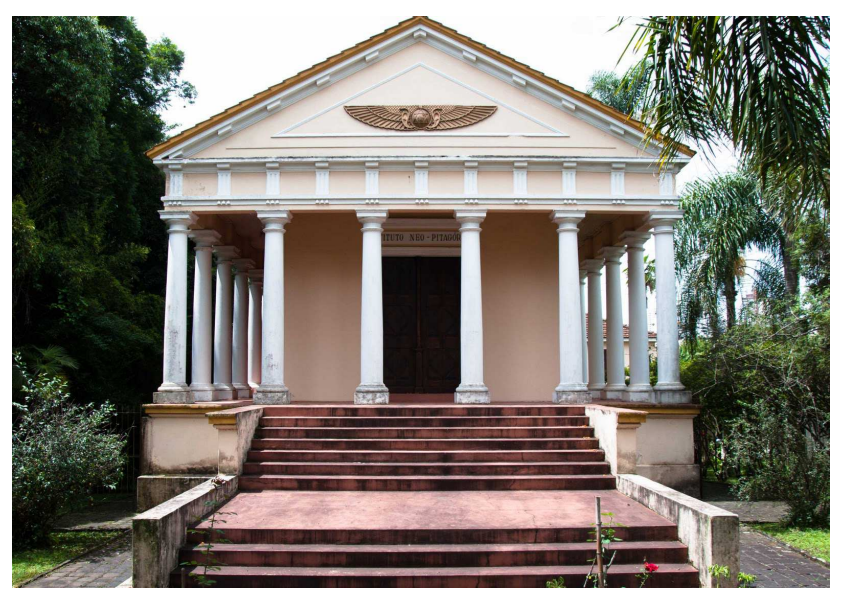

O instituto fica na Rua Professor Dario Velozzo N. ${ }^{\circ} 460$ - Vila Izabel e o prédio, conhecido como Templo das Musas, é tombado como patrimônio cultural pelo estado do Paraná. Fonte: http://www.pitagorico.org.br/.

A obra que deixou, variada e numerosa, assim como as muitas revistas que fundou e dirigiu, exploram os mais diferentes caminhos: história, pedagogia, filosofia, ciências, etc. No entanto, sua obra poética oferece encantamento. O perpétuo ambiente de vocação nostálgica em que ela se desenvolve por si só constitui poesia genuína. A Grécia antiga, a Atlântida desaparecida, a Índia milenar, são presenças que Dario Veloso a seu jeito suscita. Alma Penitente (1897) dos primeiros tempos do movimento no Paraná, Rudel (1912) e Atlântida (1938), da maturidade do poeta.

- Nestor de Castro (1867-1906): jornalista, deixou dois pequenos trabalhos Brindes (poema em prosa e contos), de denso ambiente simbolista e Bento cego $^{14}$ (monografia poublicada em 1902 sobre o "Homero rústico" do Paraná, o cantador humilde dos primeiros momentos da Província, como chamou Andrade Muricy).

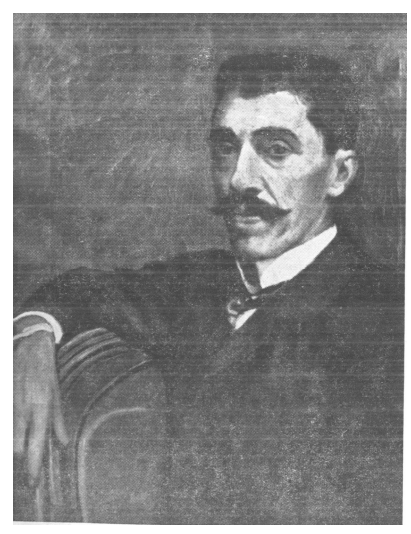

Nestor de Castro (fonte: www.poesiaspoemaseversos.com.br)

\footnotetext{
${ }^{14}$ Bento Cego era um poeta popular do interior. Buscava o contato com a tradição dos caboclos do interior para ensinar o brasileiro a amar verdadeiramente sua pátria.
} 
- João Itiberê da Cunha (1870-1953): como já dissemos foi o introdutor não apenas no Paraná, mas no Brasil, da estréia simbolista. Colega, em colégio de Bruxelas de Maeterlinck, e tendo participado do movimento de "La Jeune Belgique"", coube-lhe estrear nas letras na capital da Bélgica, com um volume de poemas em francês, Préludes, "exposto à venda no mesmo dia que Serres Cheudes", a grande estréia de Maeterlinck, informa Andrade Muricy. De retorno ao Brasil, trouxe a nova esteia em livros e informações que atearam o movimento entre nós. Foi musicista e crítico musical de valor (crônicas musicais de Jic, no jornal Correio da Manhã), além de Préludes deixou produção poética esparsa.

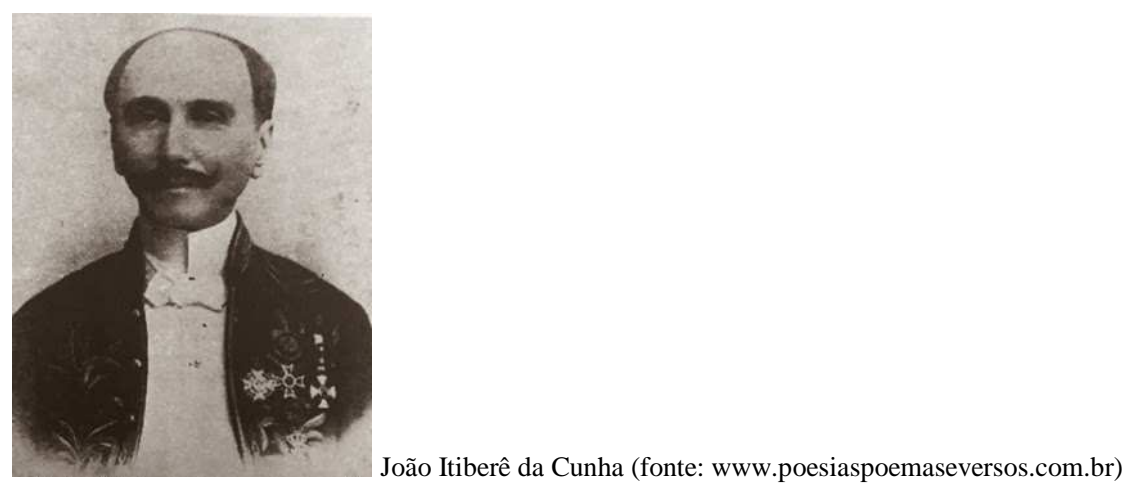

- Ricardo de Lemos (1869-1932): publicou somente o livro Ventarolas (1898), de versos humorísticos.

- Júlio Perneta (1869-1921): irmão de Emiliano e um dos fundadores de O Cenáculo. Publicou Bronzes (1897) e Malditos (1909) que são números bibliográficos de importância no movimento simbolista paranaense. Em Amor Bucólico (contos, 1898) confere ao autor o título de precursor da literatura regionalista. Quase todo o resto de sua obra, no entanto, constitui de opúsculos de campanha contra a igreja, expressivos de um espírito que se prolongaria, no Paraná, até a terceira década do século XX.

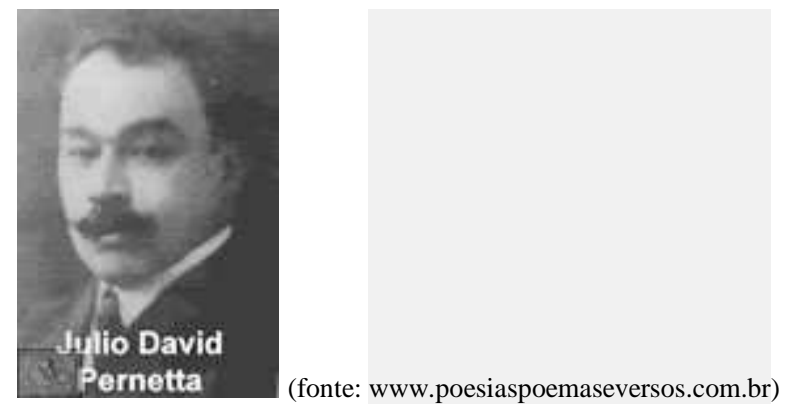

- José Henrique de Santa Rita (1872-1944): autor de poucos poemas nunca aparecidos em livro. Foi contista, novelista e tribuno. ${ }^{15}$ La Jeune Belgique foi uma revista literária e artística que apareceu em Bruxelas entre 1881 a 1897. Ela reuniu autores
como Iwan Gilkin, Georges Rodenbach, Max Waller, Valère Gille e Albert Giraud, poeta do Parnasianismo. 
- Antonio Braga (1874-????): outro dos companheiros de O Cenáculo, deixou em revistas e jornais sonetos em que o verso, impecável pela harmonia, vem no entanto marcado de acento simbolista.

- Tiago Peixoto (1876-1921): só depois de morto teve seus poemas publicados em volume O livro de Tiago Peixoto (1922).

- Leite Júnior (1876-1930): publicou Ritual (1900), tendo tido o desprazer de ver toda a sua obra sacrificada num incêndio anos mais tarde.

- Ismael Martins (1876-1926): legou-nos o volume de poemas Ciclos (1931)

- Aristides França (1879-1900): em Dolência Astral (publicação póstuma de 1911) expressa pungante melancolia.

- Adolfo Werneck (1879-1932): autor de Dona Loura (1903), Bizarrias (1908), Insônia (1921), Minha terra (1922) e Arco-íris (1923) que contém diversos sonetos e outros poemas. A obra contém todo o espectro produtivo do autor, de poemas tipicamente simbolistas até versos mais livres e leves. É o único de seus livros a conter seu poema mais famoso, "Nhundiaquara".

- Raul José Gelbcke (1879-1960): com o livro Missas (1905) fez uma das notas mais vivas do movimento no Paraná. O título do livro é explicado pela "Invocação", na qual a alma do poeta reza "missas de sete cores" a Nossa Senhora "das sete espadas". Os simbolistas aliás usavam do vocabulário litúrgico e religioso de modo frequentemente profanador e até blasfemo.

\section{PRÉ-MODERNISMO}

Ao gesto renovador dos criadores de O Cenáculo, que foi até hoje o de sentido mais profundo na história literária do Paraná, seguiu-se de perto outro gesto rebelde que, embora ainda em pleno clima simbolista, se revestiu de significação diferente. O interesse ideológico, que já se manifestara no primeiro, mas totalmente subordinado à ansiedade de beleza, tomou no segundo, posição de preemência, retardando o ritmo criador, mas estabelecendo ambiente de luta intelectual e espiritual que serviu a complexificar a vida de inteligência, embora se norteasse em sentido equívocos. Figura central desse outro movimento foi Euclides Bandeira.

- Euclides Bandeira (1876-1947): jornalista de grande brilho, polemista, contista e poeta de traços fortes de originalidade. Em torno dele agruparam-se numerosos jornalistas, poetas, contistas, romancistas, cronista inclusive muitos dos simbolistas aqui já citados - dinamizando a vida intelectual, acrescentando a 
bibliografia paranaense ressonância à obra, que aos poucos se completava, de Emiliano Perneta, Dario Veloso, Rocha Pombo, Silveira Neto, Emílio de Menezes e outros, do movimento anterior.

Egresso da carreira militar, escreveu Heréticos (1901), Ditirambos (1901), Velhas Páginas (1903), Ouropéis (1906), Prediletos (antologia de poemas preferidos) nos mostra seu anticlericalismo. O poema intitulado Sapo $^{16}$ e o soneto Sábado são marcantes criações do simbolismo brasileiro.

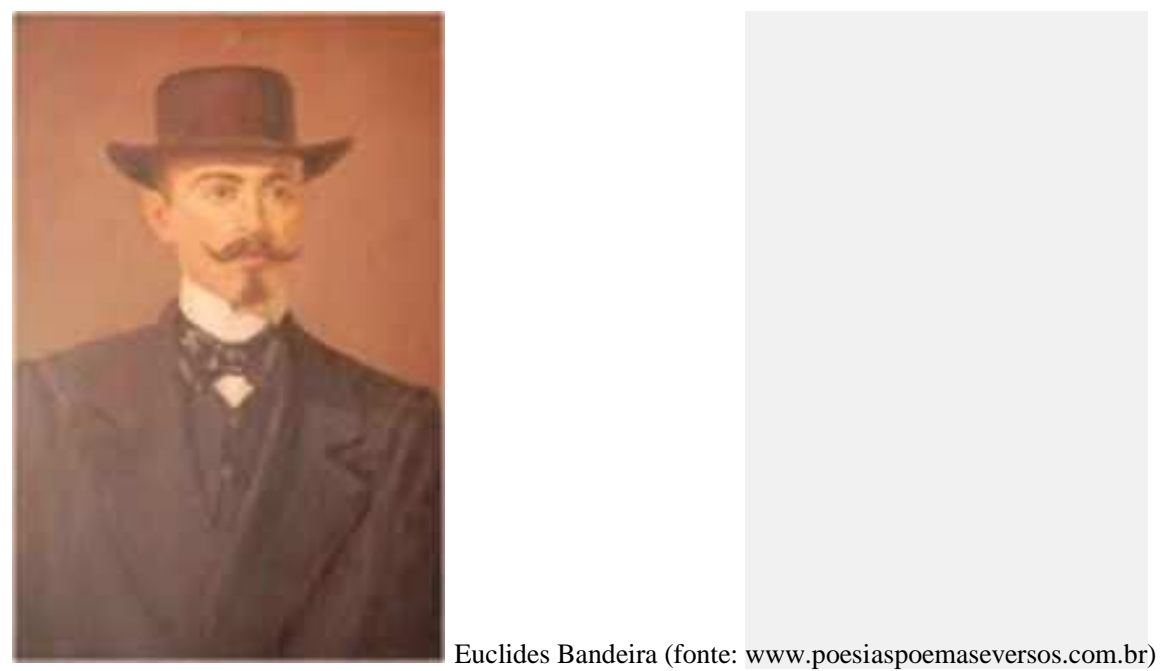

16 Pode-se dizer que o movimento ascensional está vinculado ao sentimento de sublimação, enquanto o sentido descensional está ligado às representações de castração e morte. É por essas duas extremidades que a fantasia do poeta percorre. Observa-se que nos poetas pacíficos/serenos o movimento é ascensional e naqueles mais doentios o movimento é descensional.

As imagens do sapo, da escada e da Lua concebem um sistema de representações com características ascensional. Essa metamorfose de símbolos está presente na poesia simbolista, correspondendo à dialética/paradoxo (por existir um movimento ao mesmo tempo ascensional e descensional que se completam) do desejo. É possível falar de uma verticalidade simbólica que tem numa ponta inferior as imagens do escuro, do pântano e na outra ponta, o brilho inatingível de uma estrela e a luminosidade fria da Lua. E, entre essas duas extremidades, existe a escada, que é um dos elementos mediador entre o alto e o baixo, e os configuradores do desejo imaginário através dos impulsos engrandecedores. Asas, voos, montanhas, árvores e torres são outros elementos utilizados pela poesia simbolista para retratar tal característica.

A imagem do sapo se sobressai como a que restringi a experiência escura e angustiosa do simbolista. Essa imagem está relacionada com as imagens do subterrâneo do desejo, ela se insere no sistema de representações da queda e da aspiração ascensional. Falar dele é limitar as imagens do abismo em sua vocação para o escuro, o pântano e a cova. O estudo de seu significado só se completa no momento em que se configuram as imagens complementares que redimem ou esconjuram o que há de mais desprezível no sapo.

Em "Sapo humano", Cruz e Sousa reproduz a imagem do sapo, de corpo e alma, e conclui com a glorificação comum dessa imagem. E como exemplo de outros autores que fazem uso da estética do horror e do macabro temos: Maranhão Sobrinho (Equatorial); Euclides Bandeira; Gonzaga Duque; e Alphonsus de Guimarães (Cavaleiro Ferido). Enquanto que Maurício Jubim; João Ribeiro e Alphonsus de Guimarães fazem uso da temática da escada que aponta para o símbolo fundamental que é o elemento oposto e complementar do pântano onde o poeta se encontra, a Lua. Temos a Lua, retratada nesse sentido, em "Nostalgia do Céu" de Wenceslau Queirós. Enquanto que em "Lua”, de Cruz e Sousa, vemo-la de maneira reveladora de aspecto triste, mórbido e melancólico. No entanto não vemos a Lua como uma constante na poesia simbolista apesar de seu aspecto positivo, na maioria das vezes. Vale caracterizar a ambiguidade da Lua enquanto símbolo da fatalidade amorosa e mística. 
Dentre os que rodearam Euclides Bandeira e que nas campanhas de imprensas obedeceram ao seu mando, alguns se destacaram em setores diversos da atividade intelectual.

- Alcides Munhoz (1873-1930): além de diferentes tipos de crítica e polêmicas, ou de assuntos econômicos, deixou peças teatrais e três romances - Palmos (1903), Mbá (1904) e O grande teatro (1905) - que representam amoráveis tentativas de realização de um gênero ainda no começo do século XX sem grandes possibilidade no Paraná.

- Rodrigo Otávio (1877-1944): produziu cantos de amor juvenil e extensa obra em livros, revistas e jornais. Publicou Estrela d'alva (1906), Quando floresce o amor (1908), Cânticos e Baladas (1913), Sonatinas Morosas (1922), Pela noite da vida (1923), todos de poemas, além de novelas e de preciosos trabalhos de pesquisa no terreno da história e da literatura regional.

- Clemente Ritz (1888-1935): publicou Sonhos de moço (1907), A caminho de Elêusis (1914) e Meu surrãozinho de trovas (de feição popular e tocado da sombra da morte que chegava).

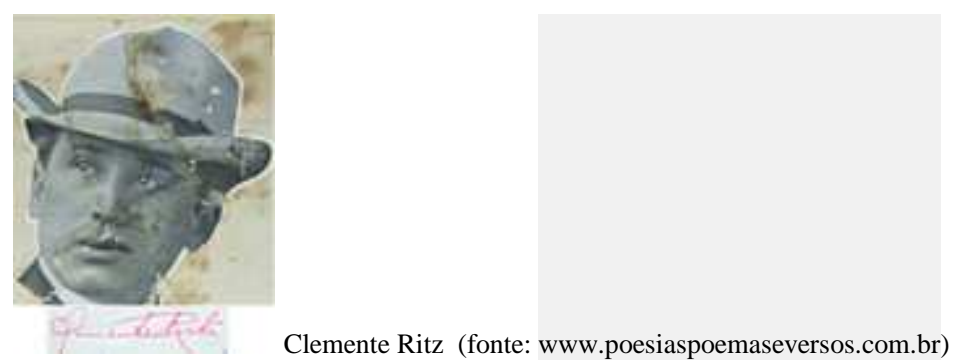

- Raul Gomes (1889-1975): de temperamento agitado e vida pontuada de sofrimentos, se apresenta como repórter, mas é de fato um admirável contista que, no entanto, derivou para o jornalismo, para a pedagogia, a linguística, a historiografia e o direito, para a luta em campo aberto pelo ideias culturais.

- Serafim França (1888-1967): seu livro principal é Canções da terra dos pinheirais (1912), reeditado mais tarde com sensíveis modificações sob o título de Cantos das lindas terras dos pinheirais (1922) encerra poemas de forma antiga (baladas, contos reais). Publicou ainda o livro de contos Barra Velha.

- Sharffenberg de Quadros (1878-1935): publicou Canções natais (1908) e em poemas anteriores não recolhidos em volume, foi um cinzelador do verso de recursos notáveis. Seu soneto Desdêmona é, entre outros, realização perdurável, pela inspiração shakesperiana.

- Leocádio Cysneiros Correia (1875-1968): com longa bibliografia em prosa e verso, inclusive comovidos "perfis espirituais" de Alcidez Munhoz, Natalina Cordeiro e Nestor de Castro, publicados todos no ano de 1922. 
- Thales Saldanha: poeta e ensaísta ${ }^{17}$

- Generoso Borges de Macedo (1875-1945): jornalista, poeta e teatrólogo. Nasceu em Guarapuava, em 23 de julho de 1875. Após os estudos primários realizados em sua cidade natal, com dezessete anos de idade, quis matricular-se no Liceu de Artes e Ofícios, no Rio de Janeiro. Não conseguiu a matrícula e, frustrado, retornou ao Sul para iniciar-se no comércio da cidade de Paranaguá. Explodira a revolução federalista e retirou-se do palco da guerra. Apagadas as mágoas partidárias, iniciou-se no jornalismo curitibano, sem contudo deixar as lides mercantis. Leitor voraz de todos os gêneros literários, poesia, romance e crítica, fossem nacionais ou estrangeiros, adquiriu sólida cultura humanística. Elegeu, na poesia, Emílio de Menezes para mentor, admirador que era de seus versos alexandrinos, o que o levaria a escrever um livro de poemas, Estrelas Cadentes, nunca publicado, mas cujos versos encontram-se nas páginas de O Sapo e da revista Azul. Retornou ao Rio de Janeiro quando foi nomeado despachante da Alfândega. Ficou nessa cidade pouco tempo, já que laços afetivos o atraíam ao Paraná, especialmente a cidade de Antonina, na qual, aos 25 anos de idade, casou-se com Otávia, aquela que ele evocava em versos como a dama dos seus castelos de ouro.

Em Curitiba, exerceu também as funções de camarista e o mandato de deputado estadual. Jornalista, poeta, cronista, encontramos seus trabalhos em jornais e revistas paranaenses. Tentou o teatro e participou, com outros parceiros, da autoria da revista Colcha de Retalhos, com música de Luís Bastos, encenada pela primeira vez no Teatro Guaíra, em 22 de julho de 1906. Publicou Semana Santa (propaganda da Liga Anticlerical Paranaense, 1902); Flâmulas, versos; Discursos e Conferências; e Terra das Maravilhas, impressões e estudos do oeste paranaense. Sócio-fundador do Centro de Letras do Paraná, membro da antiga Academia de Letras do Paraná, diplomou-se, já maduro, em Direito, pela Universidade do Paraná, em cuja turma desfrutou da amizade de companheiros como Joseph Plácido e Silva e Samuel César. Foi escolhido orador da turma de direito. Curioso que, além de estudante, participara da fundação da Universidade do Paraná, pois foi um dos professores do Curso de Comércio. Mais tarde, passou a advogar em São Paulo, onde faleceu, em 4 de março de 1945.

- Francisco Heráclito Ferreira Leite (1889-1982): poeta, cronista, comediógrafo, com três livros de poema Horas (1911), Poentes de Outono (1914) e Névoas do Sul (1924).

- Cícero França (1884-1908): autor de poemas de melancolia extrema que enfeixou em volume sob o título de Necrotério d'alma (1905).

- Heitor Stockler (1888-1975): teatrólogo e poeta.

- Gilberto Brandão: historiador, poeta, ensaísta, jurista ${ }^{18}$.

\footnotetext{
${ }^{17}$ Não foram encontrados mais dados sobre Thales Saldanha. Ele apenas é citado em vário trabalhos sobre a Literatura Paranaense sem maiores informações de sua biografia e obra.
} 
- Zeno Silva ${ }^{19}$ e Ciro Silva (1881-1968): jornalistas, escreveram em colaboração de volta de uma viagem do Egito, um livro sobre as pirâmides - Na terra das pyramides: impressoes de viagens atravez do Egypto (1926)

Ciro Silva nasceu em Campo Largo em 22 de agosto de 1881, numa casa onde funcionava uma pequena tipografia. Começou a traçar notícias, artigos e crônicas para as folhas que seu pai, Albino José da Silva, editava. E isto em localidades diferentes, tais como Paranaguá, Curitiba, Morretes e Ponta Grossa. Interessante o fato de que só depois dos 35 anos de idade se lhe manifestaria a veia poética. Boêmio, carnavalesco, secretário-geral do famoso bloco Clube dos Puritanos, orador popular, advogado, violonista, tocador de gaita de boca executava até trechos operísticos de O Guarani. Poeta, vereador, professor da Escola de Artífices do Paraná, cargo no qual se aposentou. Foi autor de várias letras para melodias de Bento Mossurunga e de Benedito Nicolau dos Santos, como Pau da Gaita (1920); Na Terra da Prontidão (1922); O Diabo atrás da Porta e Rumo ao Catete (1931). Legou pequena obra literária, com Cantos do País das Araucárias (versos, 1939 e 1979), Estrada Sem Fim... (versos, 1958); Relicário (trovas, 1968) e um livro relatando suas impressões de viagem pelo Egito, com o seu irmão Zeno, Na Terra das Pirâmides (1926).

Sócio-fundador do Centro de Letras, secretário da Academia Paranaense de Letras por 15 anos, o seu amigo inseparável o cachimbo e a sua gaitinha de boca mereceram de Euclides Bandeira um soneto interessante, que termina assim:

\footnotetext{
Teu cachimbo é, por certo, quem inspira o teu estro adorável, ó poeta!

É quem cobre de louros tua lira...

E... ou brotam versos da tua alma louca

ou chora o coração mágoa secreta

pela voz de uma gaita em tua boca!
}

- Adelina Carriel Pinheiro ${ }^{20}$ : poetisa

\footnotetext{
${ }^{18}$ Não foram encontrados mais dados sobre Gilberto Brandão. Ele apenas é citado em vário trabalhos sobre a Literatura Paranaense sem maiores informações de sua biografia e obra.

${ }^{19}$ Não foram encontrados mais dados sobre Zeno Silva. Sabe-se apenas que foi irmão de Ciro Silva. Ele apenas é citado em vário trabalhos sobre a Literatura Paranaense sem maiores informações de sua biografia e obra.

${ }^{20}$ Para saber mais sobre Adelina Carriel Pinheiro consultar a obra de MUZART, ZAHIDE LUPINACCI (org). ESCRITORAS BRASILEIRAS DO SECULO XIX, V.2. Santa Cruz do Sul: Editora EDUNISC, 2004., que mostra a produção de mulheres esquecidas pelo tempo, entre elas as três paranaenses Adelina Carriel Pinheiro, Florentina Vitel e Lucie Laval.
} 
- Ademaro Munhoz ${ }^{21}$

- Aguilar Morais ${ }^{22}$

- Aluízo França ${ }^{23}$

- Ada Macaggi (1906-1947) foi uma musicista, professora e escritora. Iniciou seus estudos em sua cidade natal, Paranaguá, o qual foi concluído na capital do Paraná. Ada destacou-se na poesia e na prosa sendo considerada uma escritora modernista . Suas principais obras: Vozes Efêmeras (livro de poesia de maior destaque da escritora de 1927), Taça (prosa de 1933), Êxtase (poesia), Arco-Íris (romance), Sangue Rico (poesia), Ímpetos (contos e poesia de 1947).

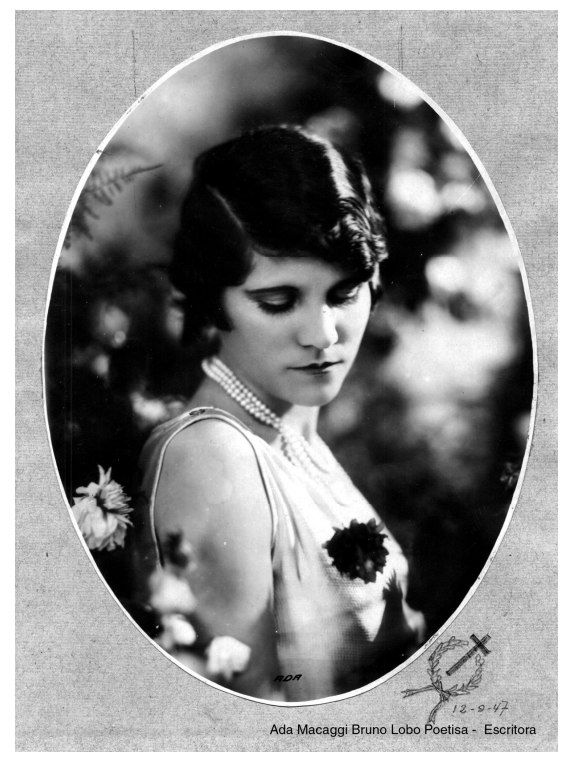

FONTE: Instituto Históricio e Geográfico de Paranaguá

- Anita Philipovsky (1886-1967): foi contista, poetisa e novelista. Quer como contista, poetisa ou novelista, desenvolveu sua atividade intelectual, notadamente no período de 1910 a 1930 , colaborando assiduamente em numerosos jornais e revistas da época. Fez parte do grupo das primeiras animadoras das letras femininas do Paraná, ladeada por Mariana Coelho, Mercedes Seiler, Maria da Luz Seiler, Zaida Zardo, Annette Macedo e Myrian Catta Preta. Em 1934, tentou publicar

${ }^{21}$ Não foram encontrados mais dados sobre Ademaro Munhoz. Ele apenas é citado em vário trabalhos sobre a Literatura Paranaense sem maiores informações de sua biografia e obra.

${ }^{22}$ Não foram encontrados mais dados sobre Aguilar Morais. Ele apenas é citado em vário trabalhos sobre a Literatura Paranaense sem maiores informações de sua biografia e obra.

${ }^{23}$ Não foram encontrados mais dados sobre Aluisio França. Ele apenas é citado em vário trabalhos sobre a Literatura Paranaense sem maiores informações de sua biografia e obra. 
um livro de contos, o qual foi inutilizado pelo editor. Os poentes da minha terra é seu poema mais divulgado, publicado pela primeira vez em Curitiba, em edição individual e integral, pela "Prata de Casa", em 1936. Mais de duas décadas depois, em 1959, o mesmo texto saiu impresso, com pequenas modificações, em antologia realizada pelo Centro Paranaense Feminino de Cultura. Consta, em Rodrigo Júnior (1938), encontrar-se em fase de editoração sua novela "Eco", além de duas outras obras do mesmo gênero, edições que não se efetivaram. Anita Philipovsky foi membro do Centro Cultural Euclides da Cunha, em Ponta Grossa.

- Gastão Raul de Forton Bousquet (1870-1918): foi um poeta, cronista, escritor (romancista e humorista) e autor teatral, além de ter excercido atividades como jornalista, redator-secretário, redator-chefe e delegado de polícia. Republicano e abolicionista, destacou-se em fins do século XIX e início do século XX.

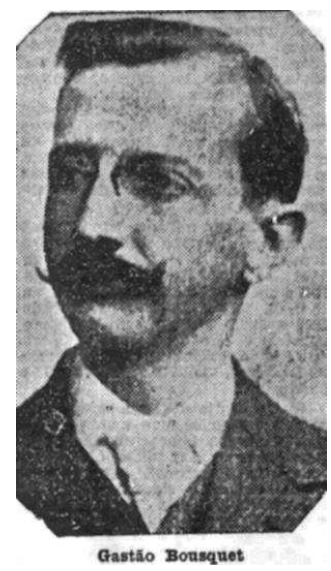

(fonte: www.poesiaspoemaseversos.com.br)

\section{- Heitor Valente ${ }^{24}$}

- Helvídio Silva (1883-19??): Nascido em Curitiba em 25 de novembro de 1883, fez seus estudos primários em colégios particulares e os exames preparatórios no Ginásio Paranaense. Passou a colaborar, ainda jovem, com 17 anos de idade, em A República e depois, com mais assiduidade, no Diário da Tarde. Lançou seu primeiro e único livro de sonetos, Grinaldas, em 1904, época em que integrava o Clube da Luta Romana como seu primeiro orador. Em 14 de abril de 1906 partiu para Recife, nomeado escriturário da Delegacia Fiscal. No ano seguinte, casou com Ermelinda com quem teve três filhos, Nilton, Hudson e Harvey. Ainda na capital pernambucana formou-se em

\footnotetext{
${ }^{24}$ Não foram encontrados mais dados sobre Heitor Valente. Ele apenas é citado em vários trabalhos sobre a Literatura Paranaense sem maiores informações de sua biografia e obra.
} 
Direito, em 16 de março de 1912. De lá, de tempos em tempos, embora os múltiplos afazeres de funcionário público e acadêmico, enviava colaborações para o vespertino Diário da Tarde com a seção de crônicas Do Norte. Andou pela Amazônia e, ao voltar ao Paraná, exerceu os cargos de magistrado na Comarca de Ponta Grossa e o mandato de deputado à Assembléia Legislativa do Estado. Membro da Ordem dos Advogados do Brasil e da União Brasileira de Juristas, consultor jurídico da Companhia Prada de Eletricidade e da Associação Beneficente 26 de Outubro, advogado da Prefeitura de Curitiba e dos Bancos do Brasil e Nacional do Comércio, afastou-se da política por ocasião do golpe de estado de 10 de novembro de 1937. Mudou-se para o Rio, reiniciando sua vida burocrática ao ingressar na Procuradoria-Geral da Fazenda, no gabinete do Dr. Francisco de Sá Filho. Jornalista, diretor-presidente da Companhia Cervejaria Adriática, professor, homem de variadas atividades, as suas produções poéticas espalhadas por jornais e revistas de Curitiba, de Recife, de Ponta Grossa e de Paranaguá, impregnadas de dor, sofrimento e morte, bem que mereciam ser publicadas para estudo e conhecimento das novas gerações. Infelizmente, informações sobre a data e o local de seu falecimento não foram localizadas.

- Ildefonso Serro Azul (1888-1949): Ildefonso Pereira Correia, mais conhecido por Ildefonso Serro Azul, nasceu em Curitiba no dia 9 de julho de 1888. Era filho do Barão do Serro Azul. Poeta, humorista, boêmio, contista, romancista e autor teatral, sócio-fundador do Centro de Letras do Paraná, tornou-se um colaborador assíduo da maioria dos jornais e revistas paranaenses. Sua bibliografia não é pequena e dela podemos destacar: Lilazes; O Eco Daquela Voz...; Saudade; Paisagens de Minha Terra, poesias; a novela Liberdade, os romances Viva o Tango!; Fazendo a América; e A Mania da Época, este publicado em capítulos pelo Diário da Tarde, em janeiro de 1927. Bem marcante é a sua contribuição para o teatro: O Pau da Gaita, com Ciro Silva; Mais Uma...; O Coração Adivinha, com Bento Mossurunga; Na Terra da Prontidão, com Ciro Silva; É Do Que Há!, com Nho Lisandro; O Tifo, com Léo Kessler; O Diabo Atrás da Porta, com Ciro Silva; Um Genro Milionário; e Rumo ao Catete, ainda com Ciro Silva; e as inéditas, Tarde Piaste!, A Mocidade Tudo Vence, Depois da Epidemia, Casamento Original, No Dia dos Reis Magos, e Um Rapto Político, com Rodrigo Júnior, baseado no rapto do Dr. João Cândido, fantasiado de mulher, pelo Tenente Carlos Eiras. Proprietário do Teatro Mignon, com Adalberto Nácar, redator do jornal humorístico O Anzol, com Alceu Chichorro, Ciro e Correia Júnior, foi responsável por várias seções de feição satírica como Arame farpado e A semana cômica, na Gazeta do Povo; A Semana rimada, no Comércio do Paraná; Escapamento Livre, em O Dia; Glosas, no Diário da Tarde e Pólvora miúda, em A Tribuna. Utilizando-se das armas do humorismo, ora assinando-se 
Barãozinho, ora Jeca Rabecão, tentava enganar-se a si próprio, vencendo os momentos trágicos de sua existência, as perdas trágicas do pai, do filho Luís Fernando, de suas irmãs, de sua mãe, do sogro e da sogra, Argentina, sempre consolado pela presença de sua esposa Constancinha. Foi nomeado fiscal do ensino secundário para o estado de São Paulo, onde morreu em 30 de junho de 1949.

- José Cadilhe (1874-1942): é natural de Antonina. A princípio mestre-escola, depois funcionário da Rede Ferroviária, decidiu-se pelo jornalismo. Militou na imprensa de Curitiba, de Paranaguá e de Ponta Grossa, no mesmo Estado. Em Ponta Grossa, foi redator e dirigiu o Diário dos Campos durante quase uma década, fundou o jornal A Cidade (1928) e foi secretário da Câmara Municipal. Temperamento polemista e impetuoso, sensibilidade de artista, marcou presença na cidade, participando de sua vida cultural e social, como jornalista, como teatrólogo, como poeta. Jornalista, esteve sempre às voltas com as questões políticas. Teatrólogo escreveu, com sucesso, peças encenadas em Ponta Grossa, Curitiba, Paranaguá e Antonina. Autor de belíssimos poemas, todos vazados nos moldes clássicos, cultivou em especial o soneto e só uma vez tentou o verso livre, quando escreveu Delirium Tremens. Pertenceu à Academia Paranaense de Letras. Faleceu em Curitiba, em 1942. Publicações poéticas: Poesias (1916); Delirium Tremens (1946).

- Lúcia Laval (1895-1914): poetisa francesa. Nasceu em Dakar, Senegal, em 19 de abril de 1895, filha de Maurício Laval e Alix Laval. Nascida na África do Norte, quando seu pai ali estava no desempenho de suas funções de diplomata francês, Lucie voltou à França para receber instrução primária. Deixou o seu país em 1908, aos 13 anos de idade, vindo para o Brasil. Com seus pais, residiu algum tempo em Minas Gerais, para, em 1911, fixar residência em Curitiba, onde viveu três anos incompletos, no entanto repletos de fulgurantes lampejos de sua criação poética.

Aos 17 anos, escreveu "Dans l'ombre", quarenta e nove poemas, escritos entre abril e outubro de 1913, em Curitiba, e publicado postumamente no Rio de Janeiro em 1924. A sua descobridora foi a intelectual Georgina Mongruel que, acompanhada pela moça, compareceu a uma reunião do Centro de Letras do Paraná. Morreu, no dia 21 de janeiro de 1914, em Curitiba, vítima de moléstia cardíaca, aos 19 anos. Em Curitiba, colaborou nos jornais e revistas da época (Gazeta do Povo, Diário da Tarde, Revista do Centro de Letras do Paraná, Álbum do Colégio Renascença, Senhorita). Em Ponta Grossa, seus inspirados poemas enriqueceram algumas páginas do Diário dos Campos, periódico que, tempos depois, critica o Centro de Letras do Paraná pelo injusto 
esquecimento da obra de Lucie Laval. Nos três anos em que viveu no Paraná, particularmente nos sete meses (abril a outubro de 1913) em que descobriu a sua alma de poetisa, conquistou para sempre um lugar entre os bons poetas paranaenses. Apesar da pálida luminosidade física, legou-nos o brilhantismo da poesia triste, porém consoladora. A palavra, artifício do existir ilimitado, foi (re)construída na busca de traçar na convulsão interior de sentimentos um caminho de reflexão e entendimento de sua própria essência.

Ressonâncias melancólicas, estrofes diáfanas de versos sem alegria, mas indisfarçadamente belos. Num abismo de contrastes de percepções e encantos a mergulhos solitários nos momentos silêncio. A poesia de Lucie Laval despetala-se em instantes de sedutor lirismo físico a contatos profundos com o "eu", desnudando-o na ausência do humano, em confissões apenas temerosas da majestade dos céus. A solidão, a tristeza, a amargura na percepção do outro tornam-se, nas linhas poéticas de Lucie Laval, sentimentos ternos e fogem de sua acepção negativa ao revelarem o perfil de uma alma sofredora e de uma aparência frágil.

Em sua poética, a solidão justifica, não é justificada. Preferindo a ausência aos momentos de presença, o que perturba e "agita" o eu-lírico é aquilo que o faz perceber-se, sentir-se e envolver-se no outro. A solidão é exposição de sentimentos dolorosos, mas saudáveis. A presença vem causar a esse equilíbrio um sofrimento tumultuado, uma ilusão, uma percepção falsa. A sensibilidade da emoção jovem aliada à capacidade de elaboração de poemas em atmosferas de melancólica ternura e esperançada tristeza tornam Lucie Laval poeta de sutil criatividade e incontestável harmonia sentimental.

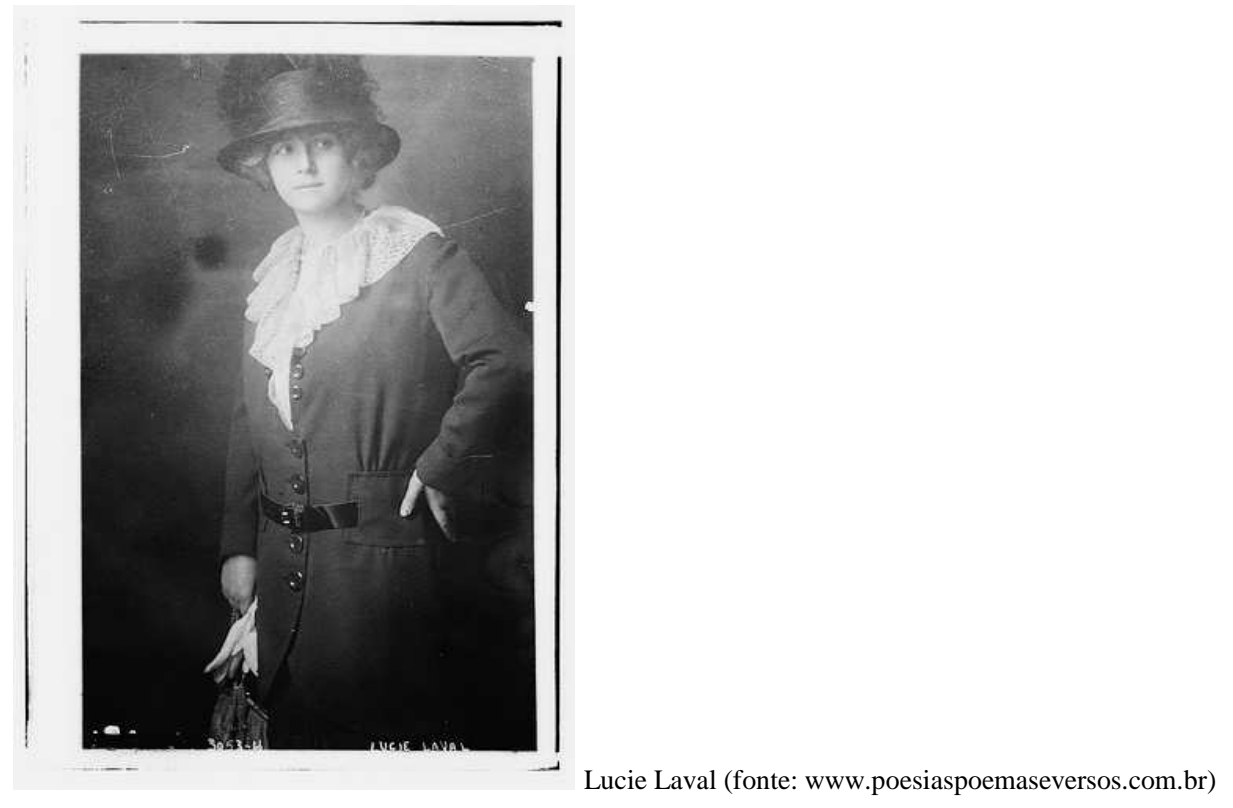


- Virgílio Moreira (1900-1973): nasceu em Campo Largo no dia 26 de junho de 1900, filho de Joaquim Antonio Moreira e Luiza Soares Moreira. Aos 38 anos mudou-se para Irati. Mais tarde, fixou-se em Imbituva, onde passou a exercer atividades na indústria madeireira. Na longa caminhada que a sua profissão impunha, agora a correr entre a capital e Irati, pouco tempo sobrou para o exercício da poesia. Mas nem por isso deixou de escrever para jornais e revistas curitibanos, lançando ainda alguns livros, como Gotas de Orvalho (versos, 1920), Tragédia Humana (poema, 1936), Rincão Natal (sonetos, em duas edições, 1937 e 1953), Cantigas do Outono (poesias, dezembro de 1952) e Meu Coração (poesias, edição do Centro de Letras do Paraná, 1955). Entrou para Academia Paranaense de Letras em 1940, estudando a vida e a obra do fundador de sua cadeira, Clemente Ritz, O Romeiro de Eleusis. No entanto, devido ao seu temperamento introvertido, arredio ao convívio mais aberto, não participava com muita assiduidade das reuniões acadêmicas e centristas - embora elevado à categoria de sócio benemérito do Centro de Letras em fevereiro de 1952 - e nem das rodas sociais do Clube Curitibano. Entre suas outras publicações vale ressaltar o Livro da Saudade (poemas), Telas Paranaenses (sonetos regionais), Da Serra da Esperança (crônicas e apreciações literárias) e Marcos da Grandeza de Irati, cidade onde viveria o resto de sua existência. Inteiramente voltado para a natureza, sem chegar a perceber que o tempo deslizava, ao se dar conta dos cabelos brancos, confessava-se no final do soneto transcrito abaixo. Faleceu em Irati, em dezembro de 1973.

- Moisés Marcondes (1859-1928), publicou juventude um livro de poemas parnasianos e mais tarde Documentos para a História do Paraná, colhidos nos arquivos portugueses. Seu trabalho "Jesuíno Marcondes, pai e patrono" mostra um panorama de todo o período do segundo império. Publicou ainda $A$ alma cristã em face do sofrimento, pequeno opúsculo de meditação espiritual.

- Eusébio Silveira da Mota (1847-1909) tinha gosto pelo estudo das obras filosóficas. A influência do seu pensamento filosófico na formação de escritores representativos do Paraná do seu tempo é estudada por Andrade Muricy, na obra $O$ símbolo à Sombra das Araucárias. Foi presidente de honra do Instituto Neopitagórico. Deixou publicados: Razões e Recursos; Recurso Extraordinário; O Evolucionismo de Spencer e outras colaborações literárias e filosóficas esparsas.

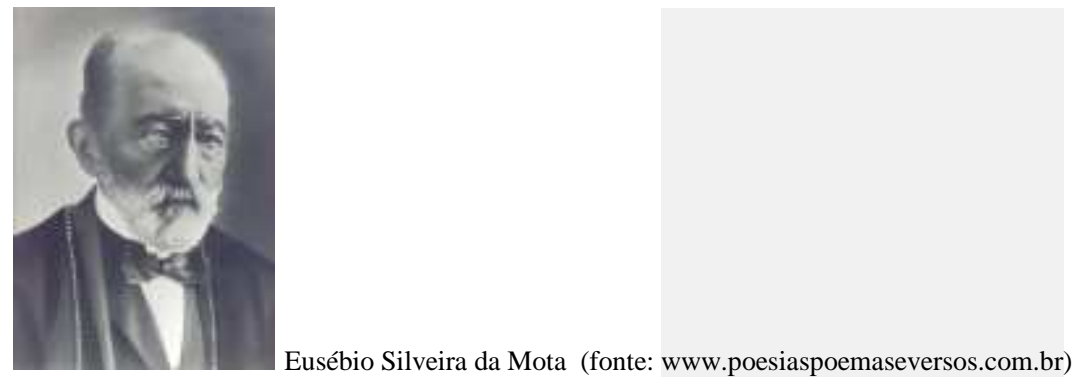


- José Cândido da Silva Muricy (1863-1943) evocou o ambiente rústico no livro Parada Morta e no memorialista de A Revolução de 93. Foi um dos primeiros a visitar e estudar a região do extremo oeste paranaense, deixou sobre o tema, além do livro Foz do Iguassu, publicado, o volume inédito Viagem ao País dos Jesuítas, cheio de observações curiosas sobre a realidade humana e a natureza daquela região.

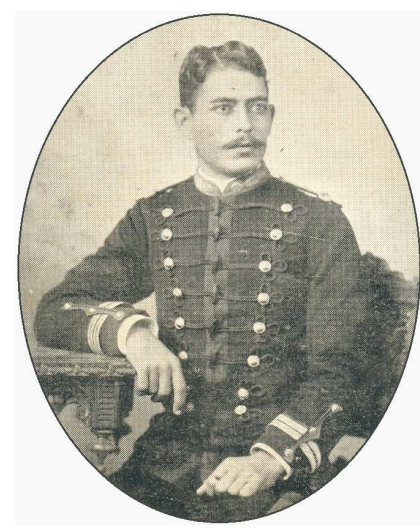

José Candido da Silva Murici (fonte: www.poesiaspoemaseversos.com.br)

- Romário Martins (1874-1948) historiógrafo, jornalista, contista, folclorista, memorialista, geógrafo, desdobrou-se em monografias sobre a natureza e a história do Paraná. Seu livro de contos Ruínas (1898) é um documento de fina sensibilidade.

- Dídio Costa (1881-1953) fez a carreira completa de oficial da Marinha de guerra. Publicou Aspectos (1912) e no último quartel da vida, já no Rio de Janeiro, promoveu como encarregado da Biblioteca da Marinha, a publicação de importantes documentos. Nasceu em Guarapuava, em 17 de agosto de 1881. Descendente de alemães, estudou Humanidades no Colégio Paranaense, em Curitiba, sob a direção do professor Claudino dos Santos. Concluídos os preparatórios, matriculouse na Escola Naval em 1899. Promovido a guarda-marinha em 1903, partiu em viagem de instrução a bordo do navio-escola Benjamin Constant, com destino aos Estados Unidos e aos países europeus. As impressões desse cruzeiro ele traduziria, mais tarde, no livro Nas Águas da Gasconha, (1939). Oficial brilhante, galgou todos os postos até o de Contra-Almirante, em outubro de 1950. Mas, ao lado do homem voltado para o mar, vale a pena citar sua curta experiência de político como prefeito de Paranaguá e como deputado estadual, chegando a ser lembrado como candidato à presidência do Estado. Foi Capitão dos Portos e Comandante da Escola de Aprendizes Marinheiros, ambos em Paranaguá. Por seus méritos, fez jus às comendas da Ordem do Mérito Naval e da Ordem Militar de Aviz, além de outras condecorações pertinentes à vida de marinheiro. Técnico abalizado, historiador, poeta, deixou várias obras, destacando-se as biografias Júlio de Noronha e Saldanha da Gama, ambas de 1944; Barroso, Tamandaré e Inhaúma, 1922; O Mar e o Brasil, 1941; Subsídios 
para a História Marítima do Brasil, em nove volumes; O Brasil e o Ciclo das Grandes Navegações, 1940, e o Elogio de seu Patrono, o Marechal Bormann, 1924. Membro de várias instituições culturais, de vários Institutos Históricos e de várias Sociedades de Geografia, do Centro de Letras do Paraná e da Academia de Letras do Paraná, casou em Curitiba com Olívia Faria, filha do político e presidente da Província do Paraná, Faria Sobrinho. Colaborador de vários periódicos, poeta, cronista, escondendo-se sob o pseudônimo de Herculano Mariz. Faleceu no Rio em 23 de março de 1953, no posto de Almirante.

- Panfilo de Assunção (1875-1952): advogado, jurista, professor catedrático da Faculdade de Direito do Paraná.

- Francisco de Azevedo Macedo (1875-1952) fez crítica literária e poesia. Colaborou com diversos jornais e revistas e publicou os livros: Estudos de Direito, Apontamentos sobre o Ministério Público do Paraná (1900), Código do Ensino (1916), Codificação do Processo Criminal, Cooperativismo, Organização Judiciária do Estado do Paraná (1919), Código do Processo Civil e Comercial, Conquista Pacífica de Guarapuava, Código de Posturas de Curitiba (1918); além de escrever poesias.

- Ermelino Agostinho de Leão (1871-1932) dedicou-se as pesquisas histórica, geográfica e econômica, sendo numerosas e de muito valor, publicadas ou inéditas, que pode compor a serviço do Paraná e do Brasil.

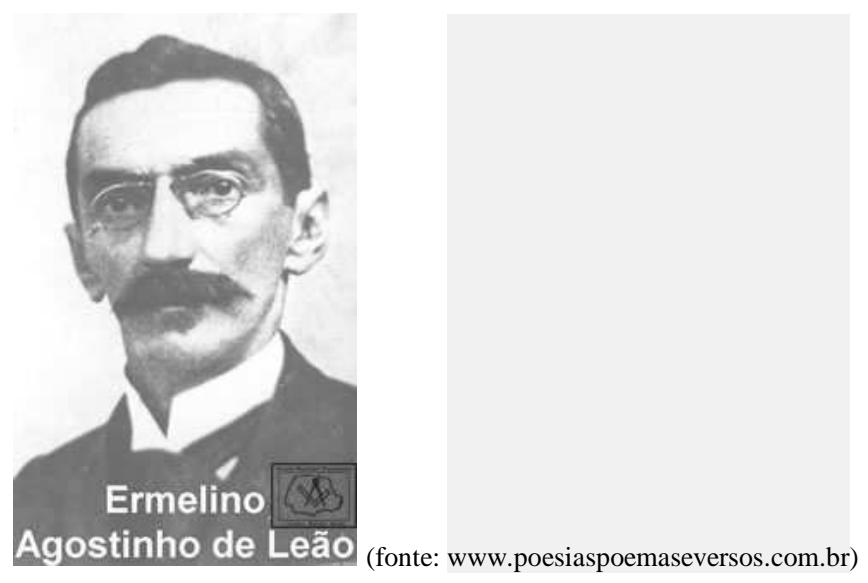

- Hugo Simas (1883-1941): foi um professor universitário e magistrado brasileiro, jornalista, escritor, formado em farmácia e em direito, tendo sido ministro público do Paraná e, posteriormente, desembargador do seu estado. Filho de Fernando Simas e Helena Gutierrez, Hugo 
Simas passou sua infância em Paranaguá onde se formou no primário. Cursou o médio e o superior no Rio de Janeiro, se formando em farmácia na Academia de Medicina do Rio de Janeiro Sua intenção em se formar farmacêutico foi de ajudar seu pai nos negócios da família. Exerceu a profissão por 5 anos, quando posteriormente resolveu cursar direito na Faculdade de Direito do Rio de Janeiro. Com grande habilidade para escrever, foi convidado para redigir o "Diário da Tarde" e o "Comércio do Paraná". Ainda nesse interesse em escrever, fez mais de 18 obras literárias e juristas, chegando ao Centro de Letras do Paraná e na Academia Paranaense de Letras. Foi escriturário da Estrada de Ferro Central do Brasil, preparador de historia natural no Internato do Colégio Pedro II; Promotor Público de Antonina, Palmeira e Rio Negro; lente de português e pedagogia da Escola Normal e de lógica, história da literatura, filosofia e história natural do Ginásio Paranaense, ambas casas educacionais de Curitiba; deputado ao Congresso Legislativo do Estado. Em 1921 mudou-se para o Rio de Janeiro, onde permaneceu alguns anos, exercendo o cargo de consultor jurídico do Lloyd Brasileiro ao mesmo tempo em que exercia a advogacia. Escreveu importantes livros dentro da área do Direito, entre eles o "Compêndio de Direito Marítimo Brasileiro" e "Código Brasileiro do Ar". De regresso ao Paraná prelecionou direito constitucional, enciclopédia jurídica, direito internacional e direito comercial na Universidade do Paraná, a qual figurou entre os fundadores, junto com Victor Ferreira do Amaral, Nilo Cairo e outros.

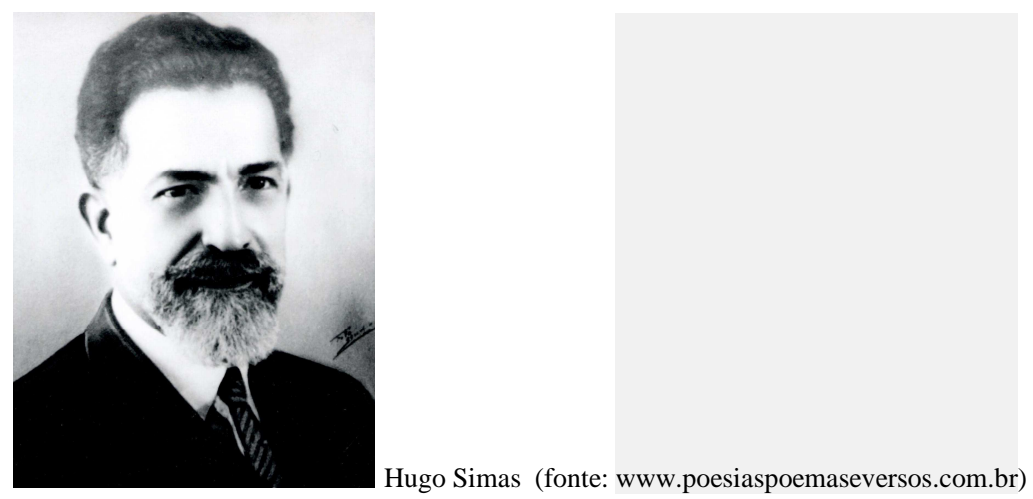

- João Perneta (1874-1933): João David Perneta era filho de Cristina Maria dos Santos e de Francisco David Antunes que, pelo modo peculiar de andar, adquiriu o apelido de 'perneta' e passou-o aos filhos como sobrenome. João era irmão do poeta Emiliano Perneta. Além deste, João teve mais três irmãos, Júlio, Manoel e Evaristo. 


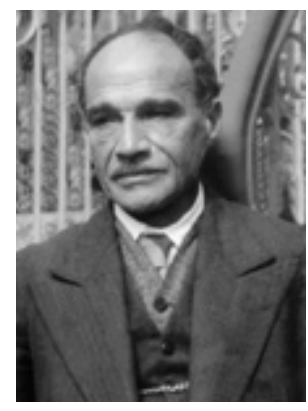

João Pernetta (fonte: www.poesiaspoemaseversos.com.br)

- Lísimaco Ferreira da Costa (1883-1941): nasceu em $1^{\circ}$ de Dezembro de 1883, filho de Antônio Ferreira da Costa e Dona Francisca Ribeiro da Costa. Em 1893, recebe o Diploma do Curso Primário. Prossegue seus estudos no Ginásio Paranaense onde, em 1906, presta concurso nas cadeiras de Física e Química. Em dezembro deste mesmo ano, casa-se com Ester Franco da Costa. No ano de 1917, forma-se em Engenharia pela Universidade Federal do Paraná. No ano seguinte, funda e organiza a Escola Agrônoma do Paraná. Em 1920, sua esposa falece. No mesmo ano é nomeado diretor do Ginásio Paranaense e Escola Normal. Um ano depois, casa-se com dona Maria Ângela da Costa. Em 1923, publica "Bases Educativas para a Organização da Nova Escola Secundária do Paraná". Dois anos após, assume o cargo de Diretor Geral do Ensino do Estado do Paraná, substituindo o então diretor, senhor Prieto Martins. Em 1926, é nomeado Inspetor Geral da Faculdade de Engenharia. No ano seguinte se torna Delegado do Estado do Paraná no Convênio dos Estados Cafeeiros. De 1928 à 1930, assume o cargo de Secretário da Fazenda, Indústria e Comércio. Em 1929, participa do Conselho Administrativo da Caixa Econômica Federal do Paraná. Falece em 23 de Julho de 1941.

O Paraná, ou melhor, Curitiba, manteve clara preemência intelectual entre as capitais do Brasil durante o período do movimento simbolista. Pouco a pouco essa preemência tombou e outras capitais como São Paulo, Rio de Janeiro, Belo Horizonte, Porto Alegre, Recife e Fortaleza mantiveram uma vida literária de maior irradiação do que Curitiba. A Revolução de 1893, que deu atmosfera para o surgimento do Movimento Simbolista, fora uma provocação vinda de fora, uma rajada que passou. Foi assim que se pode gestar a poesia de Emiliano Perneta, Silveira Neto, Dario Veloso, de quantos os acompanhavam na aventura simbolista, como também o pensamento de Eusébio da Mota, por exemplo. A geração de Euclides Bandeira, no entanto, deslocara a atividade intelectual do terreno da pura criação para o terreno da luta ideológica. E quando deflagrou a 
chamada "Campanha dos Novíssimos" 25 , por volta de 1913, a qual em seu termo final nas figuras de Andrade Muricy e de Tasso da Silveira, se apresentaria como reação espiritualista no sentido católico, não só a antiga província, iniciava o grande surto econômico que fez do Estado do Paraná alvo da atenção do Brasil, com a fundação da Universidade do Paraná (1912), uma era nova em seu destino de cultura. A hora bucólica de sonho havia acabado. As inteligências foram derivando, cada vez mais, para os interesses ideológicos, pedagógicos, políticos, econômicos ou científicos. Poucos se mantiveram na área literária. A preemência desapareceu. Mas esses poucos ainda fizeram alguma coisa.

\section{MODERNISMO: 1930-1945: esvaziamento}

A renovação modernista que, a partir de $1922^{26}$, veio agitando, transfigurando, por vezes desfigurando a literatura brasileira, teve contribuição apreciável de escritores paranaenses, como:

- Andrade Muricy (1895-1984)

- Brasílio Itibierê (1846-1913)

- Tasso da Silveira (1865-1968)

- Newton Sampaio (1913-1938)

\section{- Tasso da Silveira junto com Adelino Magalhães, Cecília Meireles, Murilo Araújo, Welington} Brandão, Henrique Abílio lançaram a Revista Festa, de ampla repercussão e influência decisiva nos

\footnotetext{
25 A Campanha dos Novíssimos foi um movimento interno do Modernismo marcado pela Ala Espiritualista. A Campanha dos Novíssimos era contra os "velhos", que eram os remanescentes do primeiro instante, e havia os "novos" que eram os companheiros de Euclides Bandeira. Os vindos por últimos eram os "novíssimos". Essa campanha fora prenunciada pelo aparecimento da revista Formal, dirigida por José Guaíba, Martins Gomes, Lacerda Pinto e Tasso da Silveira. Revista que durante dois anos pôs em comunicação Curitiba com os demais centros literários do Brasil. A campanha, propriamente, constituiu em tremenda e prolongada polêmica, da qual participaram todos os jornais paranaenses do momento, entre os "novíssimos" e os "novos". Negavam os novíssimos qualquer valor ao novos, e estes se defendiam. Uma coisa, porém, estava certa a argumentação dos novíssimos - é que os novos se tinham perdido da cultura universal e vinham se esterelizando em torno de pobres problemas. Entre os "novíssimos" figuram Andrade Muricy, Samuel Cesar, Lêonidas Loyola, Acir Guimarães, Lacerda Pinto, Martins Gomes, Tasso Silveira e outros, todos leitores de Ibsen, Maeterlinck, Novalis, Emerson, Nietzche, e por isso convencidos, de que se fazia necessário arejar o ambiente intelectual saturado de puro e infatigável anticlericalismo.

${ }^{26}$ O Modernismo tem seu marco inicial com a realização da Semana de Arte Moderna, em fevereiro de 1922 . O grupo de artistas pretendia trazer as influências das vanguardas europeias à cultura brasileira. Estas correntes europeias expunham na literatura as reflexões dos artistas sobre a realidade social e política vivida.
} 
rumos tomados pelo Modernismo brasileiro. Os do "Grupo de Festas", criaram, em face das duas correntes modernistas em atuação: a dos primitivistas de São Paulo e a dos dinamistas do Rio de Janeiro, uma terceira corrente, a espiritualista, que recebeu da crítica a qualificação de tradicionismo dinâmico.

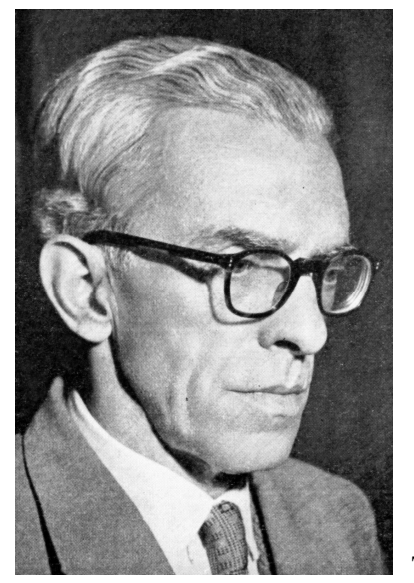

Tasso da Silveira (fonte: www.poesiaspoemaseversos.com.br)

- De Brasílio Itiberê (1896-1967) ficaram os números saídos de Festa, em contos e crônicas. Brasílio, no entanto, derivou para o dominio musical. Os seus corais situaram-no entre os mestres de prestígio na música popular brasileira.
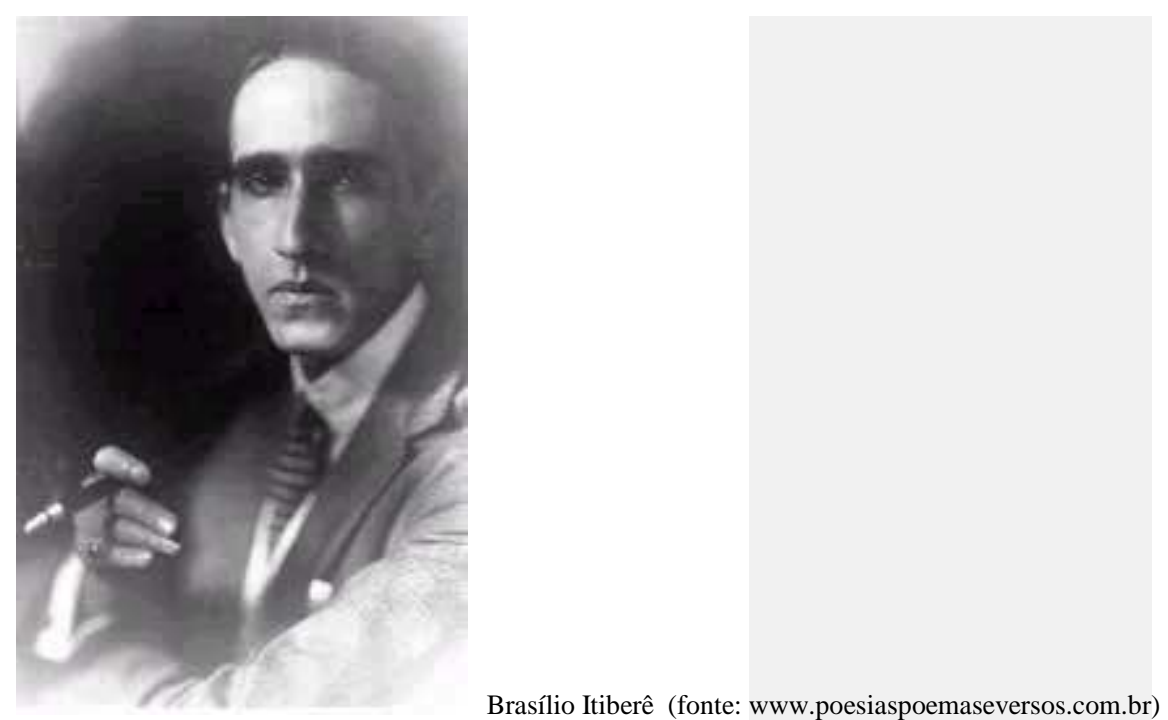

- Andrade Muricy, que além de sua colaboração nas páginas de Festa, deu ao Movimento Modernista Brasileiro a novela A Festa Inquieta, com alta marca de poesia, e que serviu de fundamento para o livro de Henrique Abílio - Crítica Pura. 


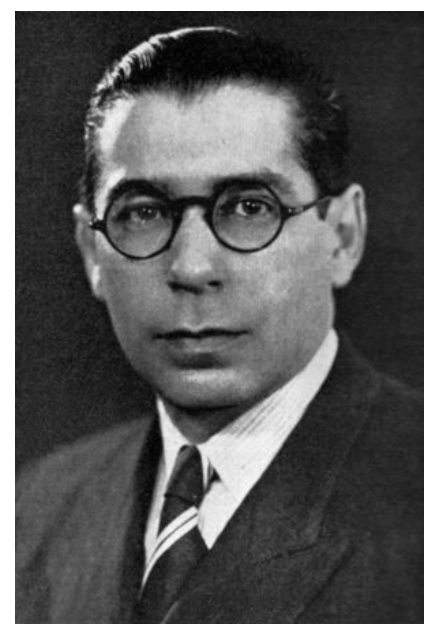

Andrade Muricy (fonte: www.poesiaspoemaseversos.com.br)

- Newton Sampaio foi médico, ensaísta, escritor e jornalista brasileiro. É considerado um dos mais importantes contistas paranaenses sendo o precursor do conto urbano moderno. $\mathrm{O}$ adolescente Newton Sampaio transferiu residência, em 1925, saindo da pequena Tomasina para estudar no Ginásio Paranaense, em Curitiba, e precocemente, passou a lecionar nesta instituição, além de colaborar para alguns jornais da capital paranaense. Ao ser admitido na Faculdade Fluminense de Medicina, transferiu-se para a cidade de Niterói. Após formado em Medicina, permanece na capital do país, porém, com a saúde bastante abalada, retornou a Curitiba e em seguida internou-se em um sanatório na cidade da Lapa onde faleceu no dia 12 de julho de 1938.
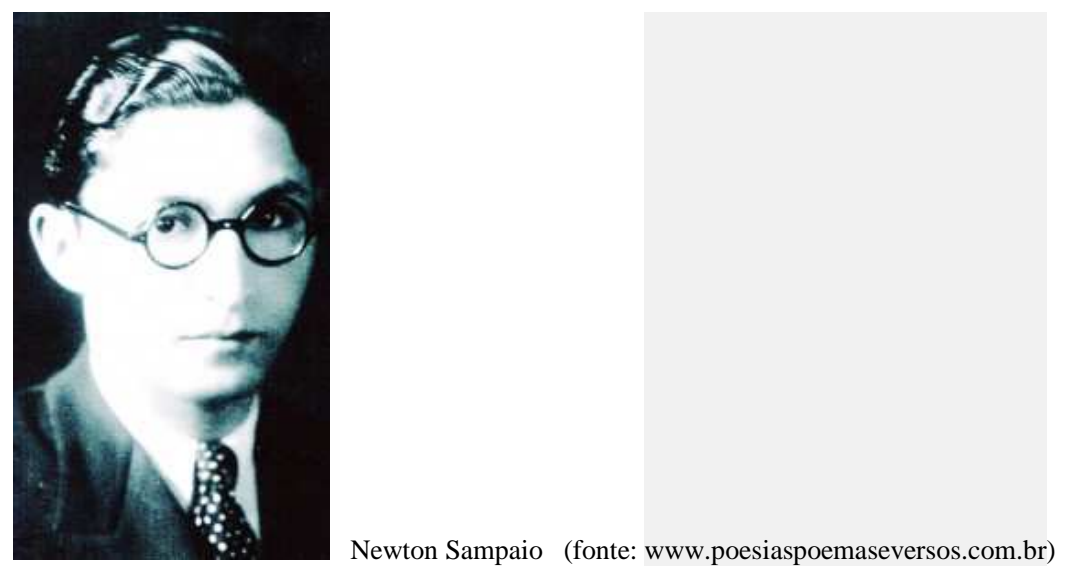

Parece que o "modernismo", da famosa Semana da Arte Moderna de São Paulo, de 1922, ainda não chegou ao Paraná! Por que é que não repercutiu no meio literário curitibano? Apenas alguns elementos da Academia Paranaense de Letras tentaram, na década de quarenta, implantar o modernismo, mas os "imortais" venceram a parada, e os modernistas tiveram que se declarar 
antiparanistas! Porém, eram muito mais paranistas justamente os que apoiaram o modernismo e não os acadêmicos que, naquele momento se portaram como reacionários. Dalton Trevisan estava entre aqueles modernistas, assim como Bento Munhoz da Rocha Neto que, em 1967, ao assumir a cadeira disse que " a Academia tem a responsabilidade diante dos jovens que estão surgindo, venham eles do panorama clássico do Paraná ou convirjam para a sua metrópole, dos quatro cantos de nossas regiões pioneiras". (Fonte: http://www.academiapr.org.br. Acesso em 30 de janeiro de 2014)

Mas surgiu um regionalismo tão tímido que não conseguiu mostrar o rosto paranaense. Dalton Trevisan, Bento Munhoz da Rocha, Samuel Guimarães da Costa, entre outros, esqueceram que, com raras exceções, não é a literatura urbana que identifica os regionalismos. Temos como exemplo os grandes: Manuel de Almeida (Memórias de um Sargento de Milícias), Machado de Assis, Raul Pompéia, ou mesmo Mário Quintana e Aloísio Azevedo, pois o cenário deles poderia ter sido a geografia de qualquer cidade do Brasil, sem perder nada da beleza de conteúdo e qualidade.

No período imediatamente após a morte dos nomes mais representativos da Literatura Paranaense como Emiliano Pernetta (1921), Rocha Pombo (1933) e Dario Veloso (1937) temos um período de esvaziamento das "letras paranaenses". Silveira Netto morre em 1942, já residindo no Rio de Janeiro; Tasso da Silveira e Andrade Muricy, mais jovens residem no Rio de Janeiro, exercendo pouca influência nas novas gerações. Valfrido Pilloto (1903-2006), Erasmo Piloto (19101992), Temístocles Linhares (1905-1993), Bento Munhoz da Rocha Netto (1905-1973) e Romário Martins, especializam-se em outras esferas das humanidades, encerrando a geração de escritores generalista do final do século XIX e início do século XX.

- Valfrido Pilloto (Mallet, 23 de abril de 1903 - Matinhos, 13 de março de 2006) foi um advogado, jornalista, escritor, ensaísta, poeta, historiador e filósofo. Foi o primeiro ocupante da cadeira número 1 da Academia Paranaense de Letras. Foi presidente do Centro de Letras do Paraná no período de 1989 a 1991.

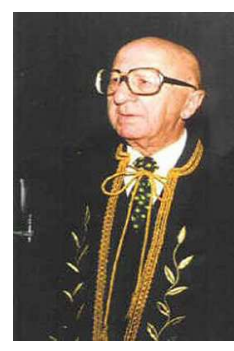

Valfrido Pilloto (fonte: www.poesiaspoemaseversos.com.br) 
- Erasmo Piloto (Rebouças, 21 de outubro de 1910 - Curitiba, maio de 1992). Em 1927 matriculou-se na Escola Normal de Curitiba. Concluindo a Escola Normal submeteu-se a concurso para ingressar na carreira de professor primário do Estado. Começou a carreira de professor em Paranaguá e depois foi para Ponta Grossa, onde exerceu o cargo de Diretor da Escola Normal e continuou lecionando Português. Posteriormente prestou concurso para a cadeira de Pedagogia e logo após transferiu-se para Curitiba para lecionar essa matéria na Escola Normal. Em abril de 1943 cria o Instituto Pestalozzi, a primeira escola que o Paraná teve, dentro de normas metodológicas avançadas e modernas. Em "Prática da Escola Serena", embora publicada há mais de 40 anos, o Erasmo Piloto nos dá os fundamentos filosóficos e metodológicos do Intituto Pestalozzi. Em 1944 ajuda o professor Raul Rodrigues Gomes a fundar o Grupo Editorial Renascimento do Paraná (GERPA), publicando no ano seguinte, Emiliano. Em 1946 ajuda Dalton Trevisan a fundar a revista Joaquim. Em 1949, assumiu a Secretaria de Educação e Cultura. Como Secretário de Educação, visitou várias escolas em todo o Paraná, inclusive escolas isoladas, ouvindo e orientando professores. O trabalho nessa época desenvolvido está contido em seu livro " Educação é Direito de Todos". Alguns anos mais tarde reuniu sobre sua orientação um grupo de professores e criou a "Associação Paranaense de Estudos Pedagógicos" que realizou pesquisas educacionais em diversas áreas. Inúmeros e valiosos trabalhos foram produzidos nessa época. A maioria deles pode ser encontrada em várias monografias e em diversos números da "Revista de Pedagogia", publicados por aquela Associação. Além das obras já citadas, escreveu João Turin (1953), A Educação no Paraná (1954), Problemas abertos no Estudo dos Sistemas Escolares para o Brasil (1958), Situações do Desenvolvimento Brasileiro e Educação (1959), Organização e Metodologia do Ensino na Primeira Série Primária nos países em desenvolvimento (1964), Graal, Fatos e Expectativas na Educação na América Latina (1965), Problemas de Educação (1966), Que se exalte em cada Mestre um Sonho! (1967), Para um Humanismo Individualista, Theodoro De Bona (1968), Dario Vellozo (1969), Mallarmé, Obras -V.1 (1973), Obras -V.2 (1976), Informe sobre Treinamento de Mestres e Alfabetização (1980), O Mural Redondo (1987).

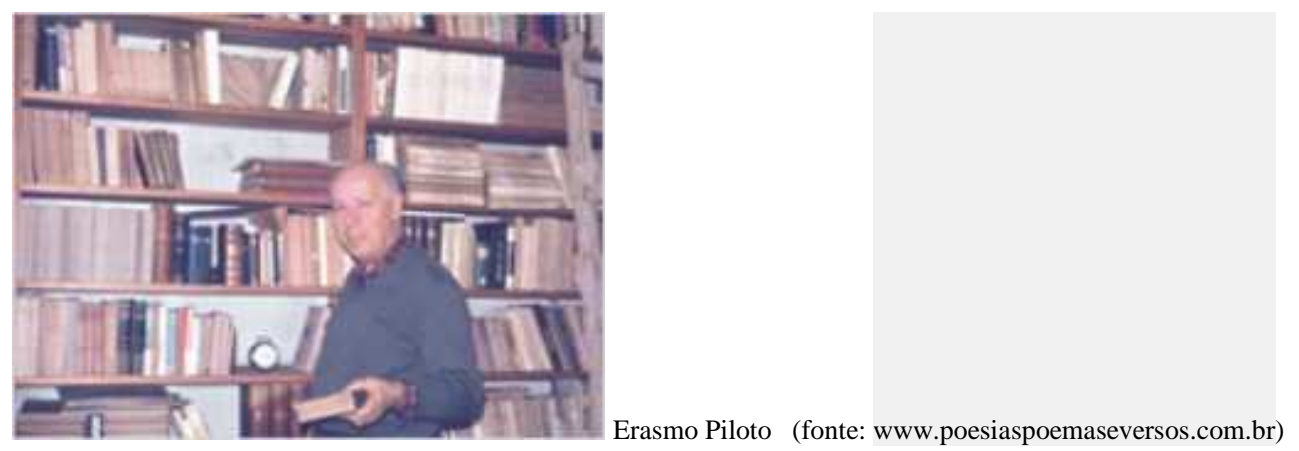


- Temístocles Linhares (Curitiba, 11 de fevereiro de 1905 - Montevidéu, 1993) foi um crítico literário, historiador e professor. Colaborou com diversos jornais (como o Correio da Manhã e O Estado de S.Paulo) e revistas (com destaque para a Joaquim) de circulação nacional. Foi docente de literatura brasileira e hispano-americana por um longo período na Universidade do Paraná, chegando a receber o título de professor emérito em 1970. Também lecionou na Universidade de Coimbra nos anos de 1965 e 1966. Publicou, entre vários artigos em revistas e jornais, Eça de Queiroz, um caso de ressentimento (1949), Paraná Vivo (1953), Introdução ao mundo do romance (1953), Gêneros poéticos (1953), Nietzsche atual e inatual (1954), Raul Pompéia (1957), Jornal da Europa (1958), Interrogações - 3 séries (1962 a 1966), História do romance brasileiro (3 volumes), História econômica do mate (1969), Diálogos sobre a poesia brasileira (1976), 22 Diálogos sobre o conto brasileiro atual (1978), Diálogos sobre o romance brasileiro (1978), Diário de um crítico - 6 volumes (2001).
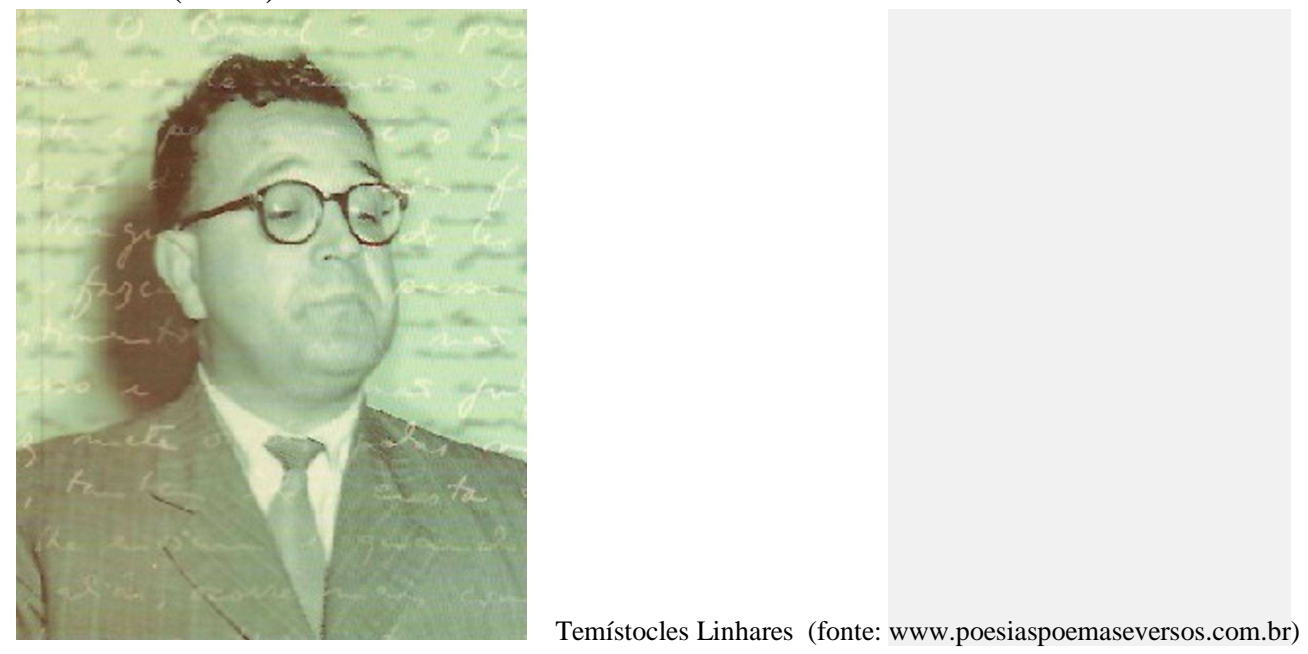

- Bento Munhoz da Rocha Netto (Paranaguá, 17 de dezembro de 1905 - Curitiba, 12 de novembro de 1973) foi engenheiro, professor, escritor, sociólogo e político. Projetou-se em âmbito nacional e internacional por sua fértil produção como ensaísta e sociólogo. Entre suas catorze obras publicadas, destacam-se: Uma Interpretação das Américas (traduzida para o inglês), Radiografia de Novembro, Mensagem da América (traduzida para o inglês), Itinerário, Perfis, Tingüís e Presença do Brasil, entre outras. 


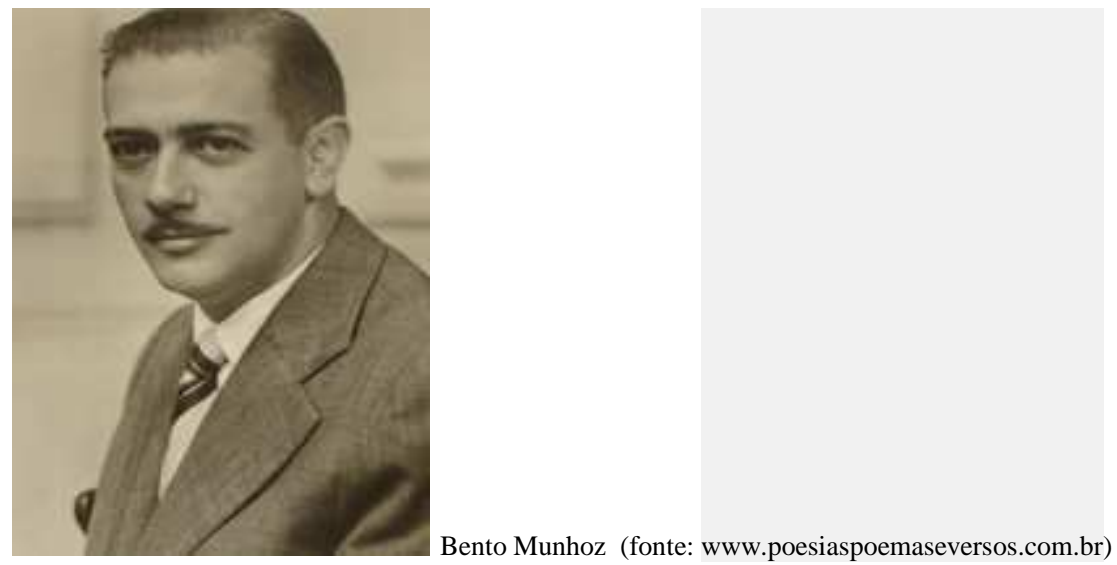

\section{O CASO DALTON TREVISAN: meados década 1940}

Mais tarde, outro movimento intelectual começa a despontar em Curitiba por meio da Revista Joaquim, que revelará jovens literatos como Dalton Trevisan (1925) que busca abrir seu espaço nos escombros de uma literatura cujo apogeu já se foi. Ele e os demais de sua geração recuperam o leme já empunhado pelos simbolistas, tanto no domínio do espaço literário local como pela imposição de novos personagens que povoam os contos, crônicas e romances. Sai o caboclo e em seu lugar novos habitantes adentram à cena: Curitiba (e o Paraná) é povoado por italianos e "polaquinhas".
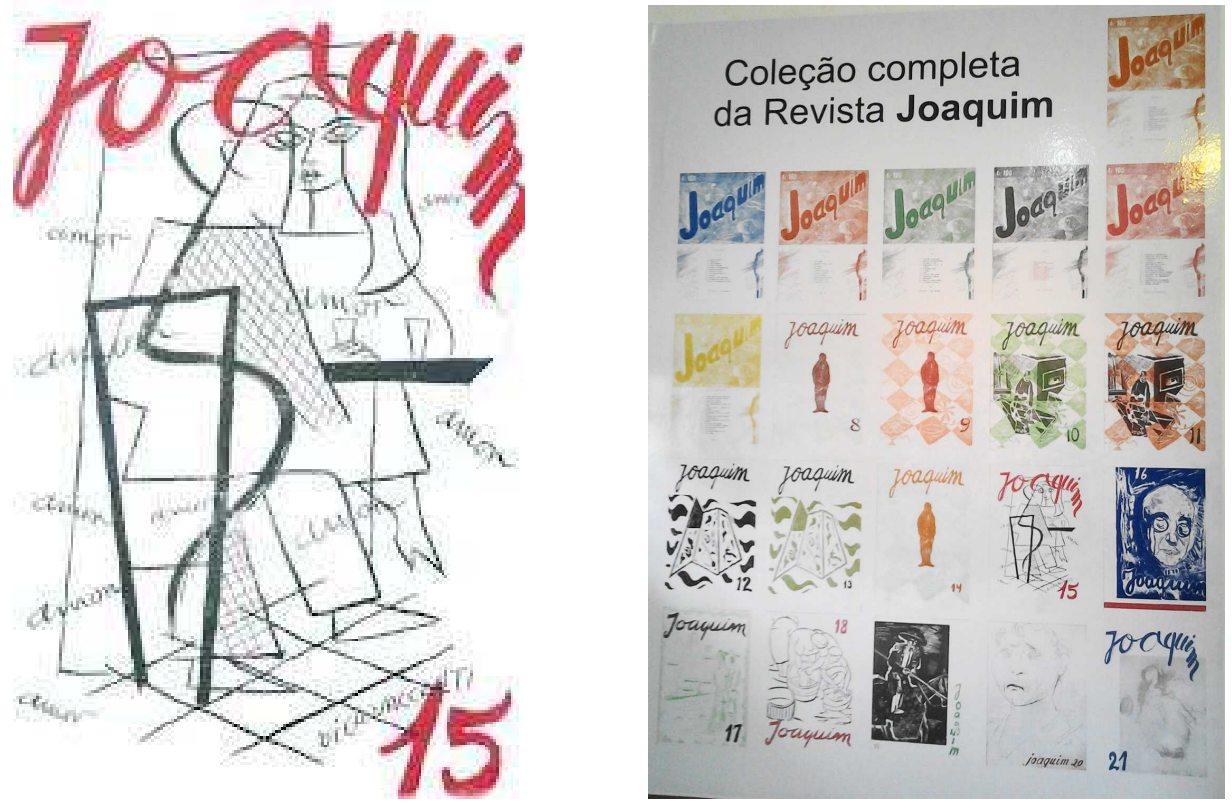

A revista teve 21 edições e circulou entre abril de 1946 e dezembro de 1948. 
Dalton Trevisan nasceu na cidade de Curitiba, em 14 de junho de 1925. Formou-se na Faculdade de Direito do Paraná e liderou o grupo literário que publicou, entre 1946 e 1948, a revista Joaquim. A publicação, que circulou até dezembro de 1948, continha o material de seus primeiros livros de ficção, incluindo Sonata ao luar (1945) e Sete anos de pastor (1948). Em 1954, publicou o Guia Histórico de Curitiba, Crônicas da Província de Curitiba, O dia de Marcos e Os domingos ou Ao armazém do Lucas, edições populares à maneira dos folhetos de feira.

A partir dos habitantes da cidade, criou personagens e situações de significado universal, em que as tramas psicológicas e os costumes são recriados por meio de uma linguagem concisa e popular, que valoriza os incidentes do cotidiano sofrido e angustiante. Publicou também Novelas nada exemplares (1959), Morte na praça (1964), Cemitério de elefantes (1964) e O vampiro de Curitiba (1965). Isolado dos meios intelectuais e concorrendo sob pseudônimo, Trevisan conquistou o primeiro lugar do I Concurso Nacional de Contos do Estado do Paraná, em 1968. Escreveu depois A guerra conjugal (1969) - mais tarde transformada em filme -, Crimes da paixão (1978) e Lincha tarado (1980). Em 1994, publicou Ah, é?, obra-prima do estilo minimalista. Seu único romance publicado é A polaquinha.

Dalton Trevisan é reconhecido como um dos maiores contistas vivos da literatura brasileira pela maioria dos críticos do país. Apesar disso, é avesso a entrevistas e exposições em órgãos de comunicação social. Por esse motivo recebeu a alcunha de "Vampiro de Curitiba", nome de um de seus livros.

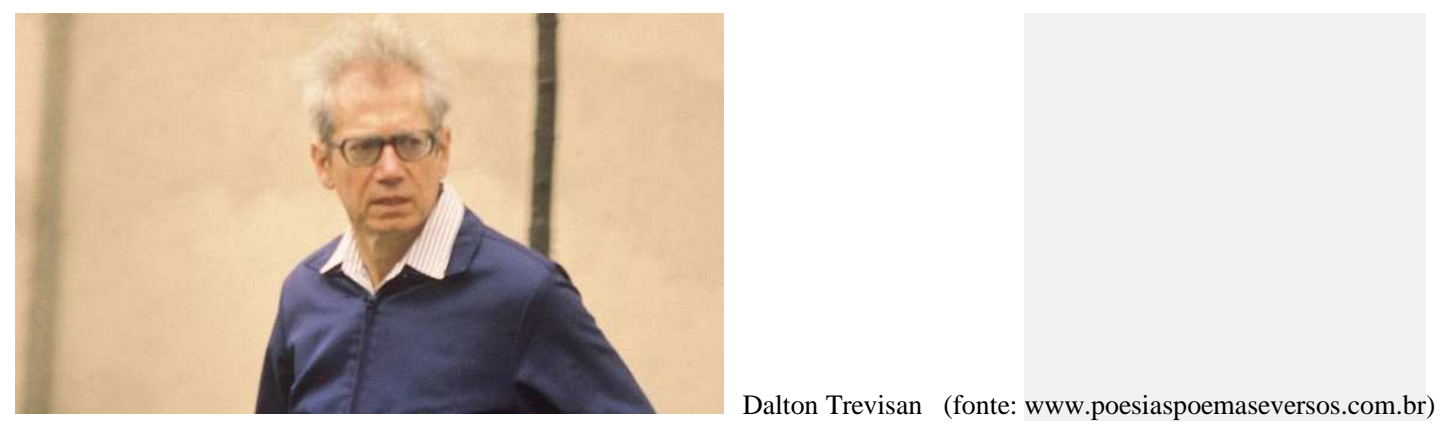




\section{PÓS-MODERNISMO}

- Jamil Snege (1939-2003) nasceu em Curitiba onde passou sua vida toda. Graduou-se em Sociologia e Política pela Pontifícia Universidade Católica do Paraná. Escritor e publicitário, dividia seu tempo entre os livros e sua agência publicitária. Publicou crônicas, quinzenalmente, no Caderno G do jornal Gazeta do Povo. Escritor reconhecido pela classe literária, publicou, entre outros, O Jardim, a Tempestade (minicontos, 1989), Como Eu Se Fiz Por Si Mesmo (memórias, 1994) e Os Verões da Grande Leitoa Branca (contos, 2000).

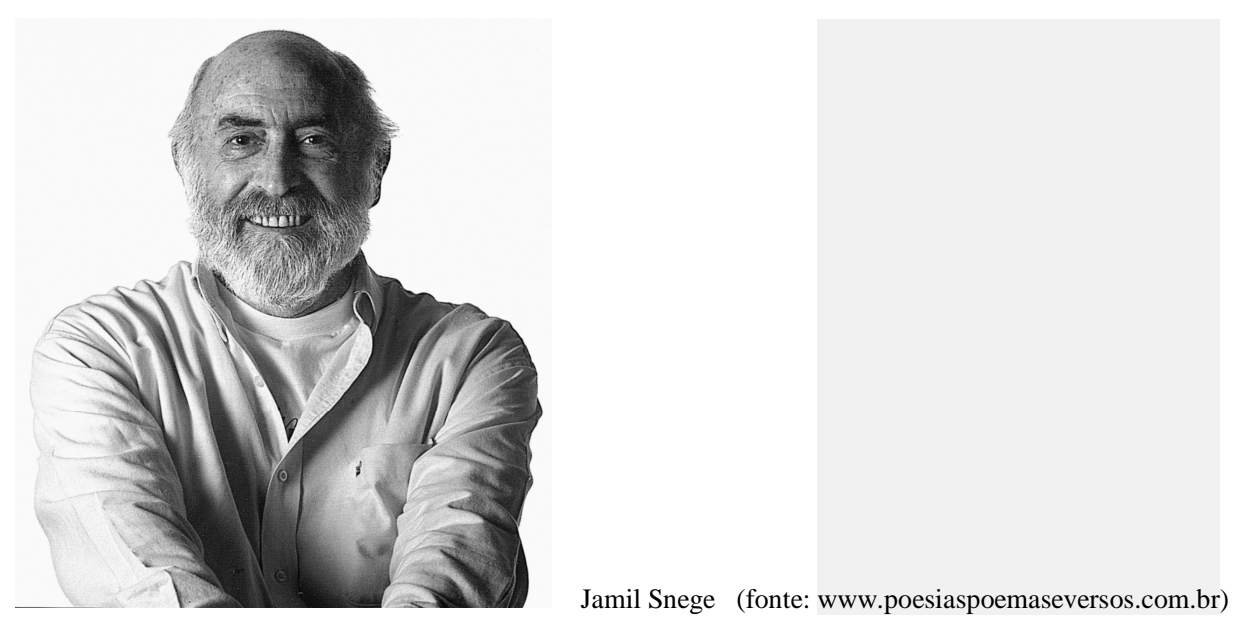

- Cristovão Tezza (1952) nasceu em Lages-SC. Romancista, contista e professor. Muda-se para Curitiba aos 11 anos de idade. Seus primeiros contatos com a arte se dão na adolescência por meio, sobretudo, do teatro: em 1968 passa a integrar o Centro Capela de Artes Populares (Cecap), dirigido por Wilson Rio Apa, no qual permanece até 1977. Rompendo com elementos tradicionais do teatro, o grupo apresenta-se em locais públicos da cidade de Curitiba, dialogando, à sua maneira, com as culturas hippie, beatnik e com as artes de vanguarda dos anos 1960. Ainda na adolescência, Tezza participa da primeira peça da dramaturga Denise Stoklos, além de outras montagens teatrais. Em 1974 viaja a Portugal para estudar letras na Universidade de Coimbra. No entanto, a universidade encontra-se fechada devido à Revolução dos Cravos, logo Tezza passa um ano viajando pela Europa. Na década de 1980 leciona, na área de letras, na Universidade Federal de Santa Catarina (UFSC) e do Paraná (UFPR). Em 1988 publica seu primeiro livro de ficção, Trapo, que o torna reconhecido nacionalmente. Seguem outros títulos bem-sucedidos e premiados, como Aventuras Provisórias e O Filho Eterno. Em 2009 abandona a vida acadêmica para dedicar-se exclusivamente à literatura. Seu romance, Um Erro Emocional, é publicado em 2010, e em 2011 lançou o volume de contos Beatriz. 


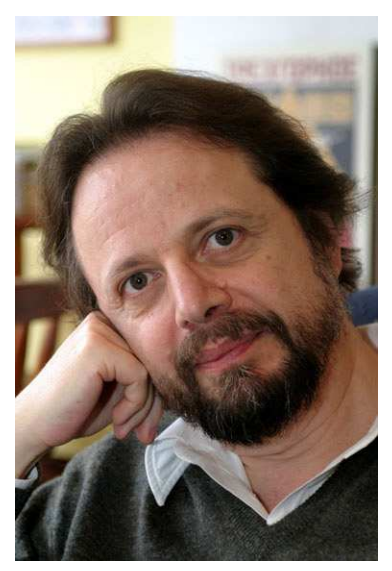

Cristóvão Tezza (fonte: www.poesiaspoemaseversos.com.br)

- Wilson Bueno (1949-2010) foi escritor, cronista e poeta paranaense. Nasceu em Jaguapitã e ainda criança se mudou para Curitiba, onde descobriu a sua vocação literária. Ao longo de sua vida construiu duas obras: a sua literatura - reconhecida como uma das mais interessantes e importantes entre os escritores brasileiros dos últimos 40 anos, que lhe rendeu 16 livros - e o jornalismo - como editor de $O$ Nicolau e colaborador em vários jornais conceituados do país. Foi apresentado aos leitores brasileiros em 1986, pelo poeta curitibano Paulo Leminski, com a publicação da coletânea de contos Bolero's Bar. Com a novela Mar Paraguayo, lançada em 1992, ganhou projeção nacional e internacional.

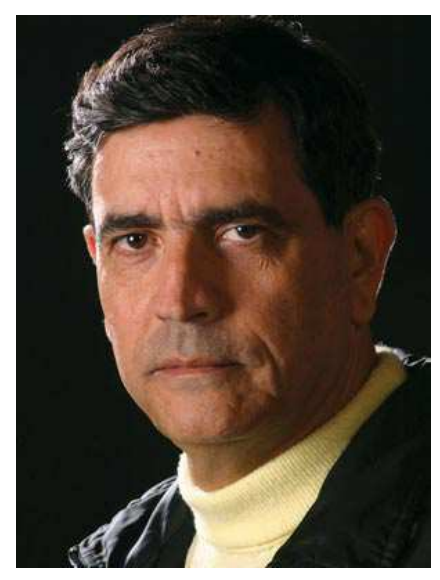

Wilson Bueno (fonte: www.poesiaspoemaseversos.com.br)

- Fábio Campana (1947) é jornalista e escritor. Diretor da editora Travessa dos Editores. Editor das revistas Et Cetera e Idéias. Colunista político dos jornais Estado do Paraná, Tribuna do Paraná , Gazeta do Paraná e Tribuna do Norte. Comentarista da rádio BandNews Curitiba e do telejornal da RIC TV. Foi Secretário de Comunicação Social da Prefeitura de Curitiba, Secretário de Estado da Comunicação Social em 3 governos. Editor da extinta revista Atenção. Editor do extinto Correio de 
Notícias. Foi colunista político do jornal Gazeta do Povo por 11 anos. Nasceu no município de Foz do Iguaçu. Publicou Restos Mortais, contos (1978), No Campo do Inimigo, contos (1981), Paraíso em Chamas, poesia (1994), O Guardador de Fantasmas, romance (1996), Todo o Sangue (2004) e O último dia de Cabeza de Vaca (2005). Vive em Curitiba desde 1961.

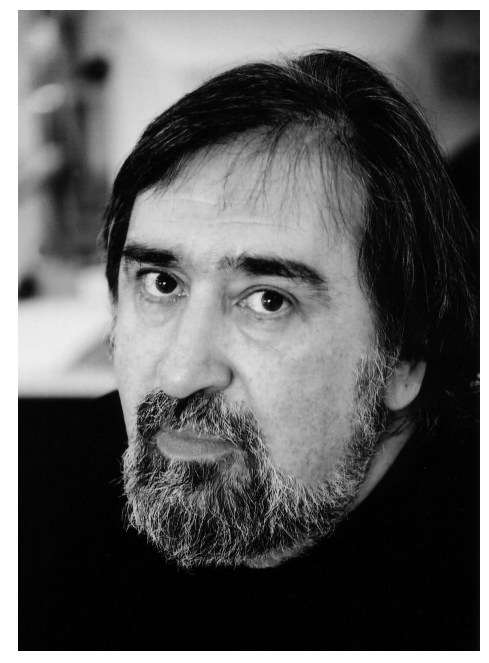

Fábio Campana (fonte: www.poesiaspoemaseversos.com.br)

- Paulo Leminski Filho (1944-1989) era poeta, romancista e tradutor. Filho de Paulo Leminski, militar de origem polonesa, e Áurea Pereira Mendes, de ascendência africana. Aos 12 anos, ingressa no Mosteiro de São Bento, em São Paulo, e adquire conhecimentos de latim, teologia, filosofia e literatura clássica. Em 1963, abandona a vocação religiosa. Viaja a Belo Horizonte para participar da Semana Nacional de Poesia de Vanguarda, e conhece Augusto de Campos, Décio Pignatari e Haroldo de Campos, criadores do movimento Poesia Concreta. No ano seguinte, publica seus primeiros poemas na revista Invenção, editada pelos concretistas, e torna-se professor de história e redação em cursos pré-vestibulares, experiência que motiva a criação de seu primeiro romance, Catatau (1976). Leminski também atua como diretor de criação e redator em agências de publicidade, o que contribui para sua atividade poética, sobretudo no aspecto da comunicação visual. Fascinado pela cultura japonesa e pelo zen-budismo, Leminski pratica judô, escreve haicais e uma biografia de Matsuo Bashô. O interesse pelos mitos gregos, por sua vez, inspira a prosa poética Metaformose. Paulo Leminski exerce atividade intensa como crítico literário e tradutor, traduzindo para o português obras de James Joyce, Samuel Beckett, Yukio Mishima, Alfred Jarry, entre outros. Colabora em revistas de vanguarda, como Raposa, Muda e Qorpo Estranho, e faz parcerias musicais com Caetano Veloso e Itamar Assumpção, entre outros. Em 1968, casa-se com a 
poeta Alice Ruiz (1946) ${ }^{27}$, com quem vive durante 20 anos, e tem três filhos: Miguel Ângelo (que morre aos dez anos), Áurea e Estrela. Em 7 de junho de 1989, o poeta morre, vítima de cirrose hepática.

A poesia de Paulo Leminski revela uma síntese entre a coloquialidade e o rigor da construção formal, herdada da estética concretista. O humor está presente em boa parte de sua obra poética, assim como a influência melódica da canção popular, dos recursos visuais da publicidade, dos provérbios e trocadilhos da cultura popular e da extrema concisão da poesia japonesa. A gíria, o palavrão e a dicção urbana também são frequentes em sua obra, como mostra o poema:

"o pauloleminski
é um cachorro louco
que deve ser morto
a pau a pedra
a fogo a pique
senão é bem capaz
o filhadaputa
de fazer chover
em nosso piquenique".

Assim como elementos formais assimilados da vanguarda, como a eliminação da pontuação, o uso exclusivo de letras minúsculas, a disposição geométrica das palavras na página, o emprego de neologismos e de palavras-valise, que multiplicam as possibilidades de significação do texto. A visualidade na obra de Leminski é mais evidente nos poemas da série sol-te, em que o poeta utiliza diferentes fontes e corpos de letras e recursos de diagramação, como no haicai visual "lua na água / alguma lua / lua alguma", em que as letras de cada verso aparecem repetidas na linha de baixo, invertidas, como se fossem sombras. Esse é um recurso icônico, ou seja, a imagem reproduz o sentido do poema (no caso, o reflexo da lua na água). $\mathrm{O}$ artesanato poético de Leminski

\footnotetext{
${ }^{27}$ Alice Ruiz (Curitiba, 22 de janeiro de 1946) Poeta e haikaista, começou a escrever contos com 9 anos de idade, e versos aos 16. Aos 26 anos publicou pela primeira vez seus poemas em revistas e jornais culturais. Lançou seu primeiro livro aos 34 anos. Alice publicou, até agora, 21 livros, entre poesia, traduções e uma história infanti. Compõe letras desde os 26 anos - tem diversas canções gravadas por parceiros e intérpretes. Lançou, em 2005, seu primeiro CD, o Paralelas, em parceria com Alzira Espíndola, pela Duncan Discos, com as participações especialíssimas de Zélia Duncan e Arnaldo Antunes. Antes da publicação de seu primeiro livro, Navalhanaliga, em dezembro de 1980, já havia escrito textos feministas, no início dos anos 1970 e editado algumas revistas, além de textos publicitários e roteiros de histórias em quadrinhos. Alguns de seus primeiros poemas foram publicados somente em 1984, quando lançou Pelos Pêlos pela Brasiliense. Já ganhou vários prêmios, incluindo o Jabuti de Poesia, de 1989, pelo livro Vice Versos e o Jabuti de Poesia, de 2009, pelo livro Dois em Um. Tem poemas traduzidos e publicados em antologias nos Estados Unidos, Bélgica, México, Argentina, Espanha e Irlanda, tendo sido também convidada como palestrante na Bienal de Lenguas da América no México e na Europalia Brasil em Bruxelas.
} 
valoriza ainda recursos da poesia tradicional, como as rimas, que são essenciais para a estrutura rítmica de seus poemas.

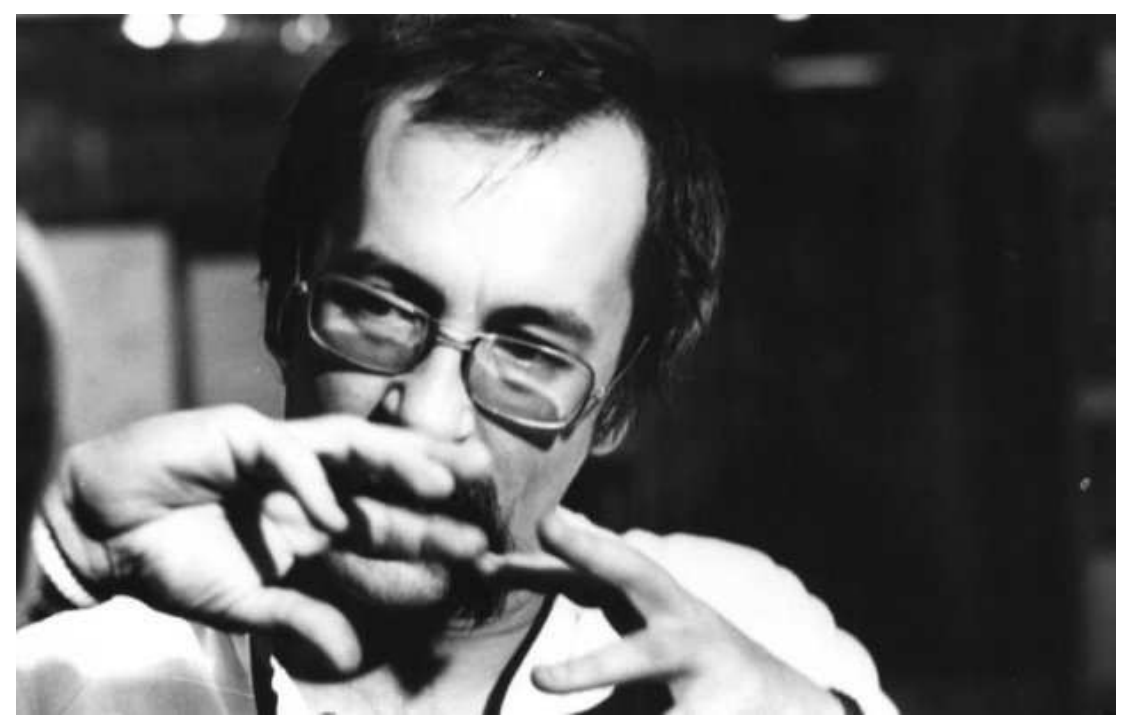

Paulo Leminski (fonte: Gazeta do Povo de 08/11/2011)

Os primeiros livros do autor, Não Fosse Isso e Era Menos / Não Fosse Tanto e Era Quase e Polonaises (1980, editora do autor), foram reunidos, com o acréscimo de novos poemas, em Caprichos e Relaxos (1983). Em Distraídos Venceremos (1987), o poeta curitibano mantém o uso de recursos estilísticos como o humor, os trocadilhos e as rimas inusitadas, em peças densas e reflexivas que discutem temas relacionados à história, à leitura, ao amor, à perda da fé religiosa, e sobretudo à própria poesia A prosa de ficção de Leminski inclui os romances Catatau (1976), Agora É que São Elas (1984), Metaformose (1994) e o livro de contos O Gozo Fabuloso (2004).

Outra faceta singular da obra de Leminski é o ciclo de biografias que ele escreve (Jesus Cristo, Leon Trotsky, Matsuo Bashô, Cruz e Sousa), reunidas no volume póstumo intitulado Vida (1990). Nesses breves relatos, o poeta curitibano faz um cruzamento de informações biográficas, históricas, literárias e culturais, numa prosa de leitura mais acessível, entre a crônica jornalística e o ensaio.O trabalho de Leminski como tradutor não é menos notável. O poeta traduz, entre outras obras, Satiricon, de Petrônio, diretamente do latim; o relato Sol e Aço, de Yukio Mishima, e haicais de Bashô a partir dos originais japoneses; Supermacho, de Alfred Jarry, do francês; além de poemas e novelas do escritor irlandês James Joyce. Paulo Leminski deixou ainda um livro de literatura infantil, Guerra Dentro da Gente (1988); uma coletânea de ensaios, Anseios Crípticos (1986); e dezenas de parcerias musicais feitas com músicos como Caetano Veloso, Moraes Moreira, Arnaldo Antunes e Itamar Assumpção. Sua correspondência com Régis Bonvicino é publicada no livro 
Envie Meu Dicionário (1998), que reúne ainda textos críticos de autores como Carlos Ávila e o Boris Schnaiderman sobre o trabalho do poeta curitibano.

- Luci Collin (nasceu em 1964) é escritora, poeta e tradutora, nasceu em Curitiba. É formada em piano (Escola de Música e Belas Artes do Paraná 1980), letras português/inglês (Universidade Federal do Paraná 1989), percussão clássica (Escola de Música e Belas Artes do Paraná 1990). Doutorada em estudos lingüísticos e literários em inglês e pós-doutorado em literatura irlandesa pela Universidade de São Paulo. Já lecionou fora do país e atualmente é uma das professoras da Universidade Federal do Paraná, lecionando literatura de língua inglesa e tradução literária. Participou de antologias nacionais e internacionais (Alemanha, Argentina, EUA, Uruguai), recebeu prêmios de concursos de literatura no Brasil e nos Estados Unidos. Além de ter sido a escritora brasileira que representou o Projeto Literário no EXPO 2000 em Hannover. Seus livros de destaque são: Estarrecer, Ondas Azuis, Precioso Impreciso, Inescritos e Acasos Pensados. O forte da escritora são os poemas e contos, contendo muita ficção. Alguns de seus textos dramáticos viraram inspiração para autos teatrais, como Acasos Perdidos. Luci Collin possui vários artigos e textos em revistas e jornais do Paraná (Gazeta do Povo, Jornal Rascunho), São Paulo (Caderno de Sábado, Germina Revista Literária), Minas Gerais (Diário Regional). Também traduziu Gary Snyder, Gertrude Stein, E. E. Cummings, Eiléan Ní Chuilleanáin e Jerome Rothenberg, entre outros

- Domingos Pellegrini (nasceu em 1949). Filho de um barbeiro e de uma dona de pensão, desde pequeno ouviu muitos "causos" contados por viajantes na barbearia de seu pai ou na pensão da sua mãe. Formado em Letras, trabalha como jornalista. Lançou o primeiro livro em 1977, O homem vermelho, uma coletânea de contos. Com ele recebeu o Prêmio Jabuti, um dos mais importantes prêmios literários do país. Nesse mesmo ano, lançou uma nova coletânea de contos, Os meninos. Além da literatura, escreve para jornais e revistas e faz trabalhos publicitários. Entre as suas obras destacam-se Terra Vermelha, que conta a história da colonização do Paraná, O Caso da Chácara Chão.

- Manoel Carlos Karam (1947-2007) era escritor, dramaturgo e jornalista. Escreveu e dirigiu vinte peças de teatro na década de 1970 e, a partir dos anos 1980, passou a dedicar-se aos livros, vencendo o prêmio Cruz e Souza de Literatura, da Fundação Catarinense de Cultura, em 1995, com a obra Cebola. Como jornalista, trabalhou na RPC TV, nos jornais O Estado do Paraná, Tribuna do Paraná e na prefeitura de Curitiba. Trabalhou também em campanhas políticas, como a do ex-governador Jaime Lerner. O escritor deixou crônicas inéditas, e outros textos que serão publicados no futuro. Em 2008, foi lançado Jornal da guerra contra os taedos 
- Miguel Sanches Neto (nasceu em 1965) nasceu no seio de uma família de agricultores de Bela Vista do Paraíso mas criado em Peabiru, pequenos municípios do interior do Paraná, o autor tornou-se um dos mais importantes críticos literários contemporâneos do país. Além de ser docente da UEPG, com título de doutorado em Teoria Literária pela Unicamp, escreve para a Gazeta do Povo e a Revista Carta Capital. Embora o gosto por escrever venha desde sua adolescência, o escritor começou a ser reconhecido internacionalmente a partir do lançamento do livro Chove sobre minha infância pela Editora Record em 2000, obra já traduzida para a língua espanhola. Desde então, é um dos nomes mais representativos da nova literatura brasileira.

No romance Um amor anarquista, de 2005, narra a história de um grupo de imigrantes italianos da cidade de Palmeira, interior do Paraná que, no final do século XIX, funda a Colônia Socialista Cecília e tenta implantar o amor livre. Escritor eclético, tem navegado por diversos gêneros, porém tem o alicerce de sua obra no romance.

\section{A SÍNTESE DA POESIA PARANAENSE: Helena Kolody}

Helena Kolody (1912-2004) seus pais foram imigrantes ucranianos que se conheceram no Brasil. Helena passou parte da infância na cidade de Rio Negro, onde fez o curso primário. Estudou piano, pintura e, aos doze anos, fez seus primeiros versos. Seu primeiro poema publicado foi $A$ Lágrima, aos 16 anos de idade, e a divulgação de seus trabalhos, na época, era através da revista Marinha, de Paranaguá.

Aos 20 anos, Helena iniciou a carreira de professora do Ensino Médio e inspetora de escola pública. Lecionou no Instituto de Educação de Curitiba por 23 anos. Helena Kolody, segundo o que consta em seu livro Viagem no Espelho, foi professora da Escola de Professores da cidade de Jacarezinho, onde lecionou por vários anos. Seu primeiro livro, publicado em 1941, foi Paisagem Interior, dedicado a seu pai, Miguel Kolody, que faleceu dois meses antes da publicação. 


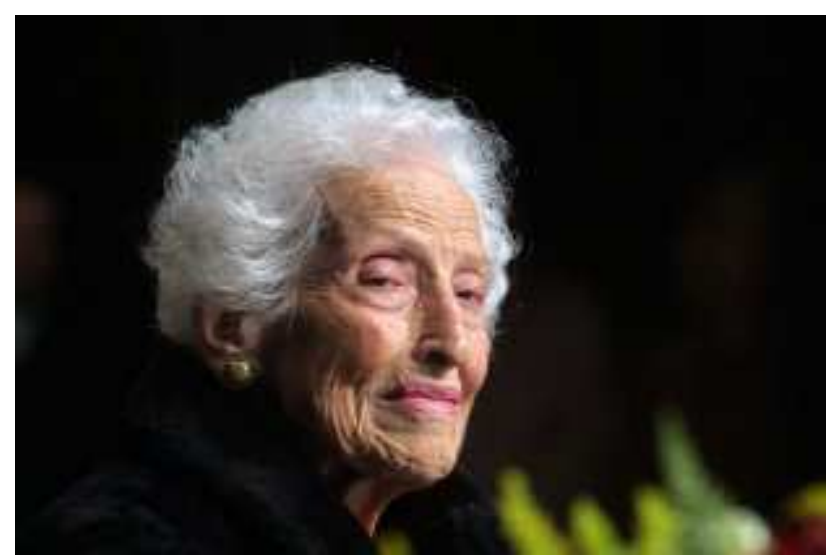

Helena Kolody (fonte: Gazeta do Povo de 08/11/2011)

Helena se tornou uma das poetisas mais importantes do Paraná, e praticava principalmente o haicai, que é uma forma poética de origem japonesa, cuja característica é a concisão, ou seja, a arte de dizer o máximo com o mínimo. Foi a primeira mulher a publicar haicais no Brasil, em 1941.

\section{Um Brasil Diferente: WILSON MARTINS}

Nas questões extraliterárias surge uma nova geração que trabalha a partir de outra matriz informadora, que busca construir uma identidade paranaense não por sua similaridade ao nacional, mas pelo que tem de peculiar, num movimento oposto aos dos literatos do século XIX (que visavam diluir os elementos de diferença). O Paraná, devido à história, à localização geográfica e ao povo "alvo e europeu", será diferente, tendo em Wilson Martins (1921-2010), paulista, a melhor tradução.

- Wilson Martins (1921-2010) foi um magistrado, professor, escritor, jornalista, historiador e crítico literário.Com apenas 16 anos de idade, Wilson já era revisor no Jornal Gazeta do Povo como prestador de serviço, sendo contratado somente em 1945 como funcionário do jornal . Formou-se em Direito, mas após concluir um curso de especialização literária em Paris, passou a dedicar-se exclusivamente à literatura, como professor e crítico. Ministrou aulas na UFPR, e durante anos foi professor de Literatura Brasileira na New York University, aposentando-se deste cargo em 1992, quando foi homenageado com o título de Professor Emérito.

Escritor respeitado, é autor da obra em 7 volumes História da Inteligência Brasileira; escreveu também A ideia modernista, Crítica literária no Brasil e A palavra escrita, entre outros. Foi durante 25 anos crítico literário de O Estado de S. Paulo e também do Jornal do Brasil. Foi colunista da Gazeta do Povo e do O Globo. 
Recebeu prêmios como o Jabuti, da Câmara Brasileira do Livro, por duas vezes, por volumes do livro "História da Inteligência Brasileira", e o prêmio Machado de Assis, da Academia Brasileira de Letras, em 2002, pelo conjunto de sua obra.

Em 1955, Wilson Martins publica “Um Brasil Diferente”, um misto de estudo históricosociológico-linguístico, em que dará sua interpretação ao processo de aculturação no Paraná. Dialoga com Giberto Freyre, propondo que ao processo apontado em Casa Grande \& Senzala se contraponha um outro Brasil, o meridional. Portador de identidade e cultura diversas da do Brasil tropical, este Brasil sulino tem suas peculiaridades assentadas na questão do clima temperado e na colonização européia do final do século XIX.

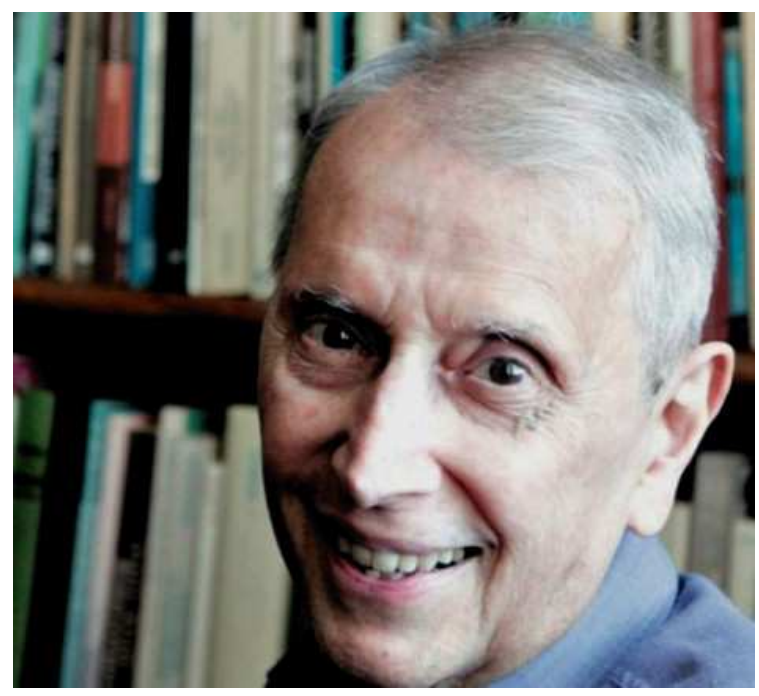

Wilson Martins (fonte: www.poesiaspoemaseversos.com.br)

\section{CONTEMPORANIEDADE: nova geração de autores paranaenses - O SÉCULO XXI}

A editora curitibana Travessa dos Editores publicou em dezembro de 2013 a coletânea LIVRO DOS NOVOS, que reúne 16 contos de autores paranaenses ou radicados no Estado, todos com idade entre 20 a 30 anos. O prefácio da edição é de autoria do escritor Luiz Bras, e a organização de Adriana Sydor. Participam da antologia os seguintes nomes:

- Ana Figueiredo (Curitiba,1992)

- Arthur Tertuliano (Recife, 1987 - reside em Curitiba)

- Celso Alves (Ponta Grossa, 1988 - reside em Curitiba desde 2007) 
- Cristiano Castilho (Curitiba, 1984)

- Daniel Zanella (Curitiba, 1985)

- Dédallo Neves (Curitiba, 1992)

- Felipe Franco Munhoz (São Paulo, 1992 reside em São Paulo)

- Felipe Kryminice (Paranaguá, 1990 - reside em Curitiba)

- Francine Porfirio (Curitiba, 1989)

- Guylherme Custódio (Curitiba, 1987)

- Marco Antonio Santos (Curitiba, 1989)

- Melissa R. Araujo (Curitiba, 1992)

- Renan Machado (Ponta Grossa, 1992 - reside em Curitiba desde 1998)

- Rodrigo Araújo (Colombo, 1983)

- Walter Bach (Canoinhas, 1989 - reside em Curitiba desde 1988)

- Yuri Al'Hanati (Rio de Janeiro, 1986 - reside em Curitiba desde 2004)

A proposta do livro é de espiar o futuro. "As reflexões de uma geração que se apresenta para conduzir o mundo a partir dessas horas que vivemos constituem o carro-chefe da coletânea", explica a organizadora e também escritora, Adriana Sydor. "É uma maneira de quase adivinharmos os novos rumos", afirma. A seleção abarca escritores entre 20 e 30 anos, que enviaram seus textos para a editora durante o último ano. Mais da metade é formada ou trabalha na área de comunicação, como jornalismo e publicidade. "Não foi tarefa fácil, pois há mais escritores prontos, maduros, preparados para entrar no mercado do que esperávamos inicialmente. Os escolhidos, na verdade, representam um número muito maior de jovens que têm preocupação e possibilidades com a escrita e a comunicação", conta Adriana.

O Jornal Cândido, da Biblioteca Pública do Paraná, em sua edição de número 25 (agosto de 2013), traz extensa matéria sobre a Literatura Paranaense. Assinada pelo professor e escritor Paulo Venturelli, o artigo viaja ao passado para resgatar nomes já consagrados (e outros que deveriam ser) e chega ao presente falando sobre a novíssima safra de escritores contemporâneos. Entre essa nova safra aparecem os seguintes nomes:

- Carlos Machado (Curitiba, 1977), músico, compositor, escritor e professor de literatura brasileira. É autor dos contos de A Voz do Outro e Nós da Província: Diálogos Com o Carbono e 
do romance Balada de uma Retina Sul-americana. No quarto livro, a novela Poeira fria, um narrador em crise fala com o terapeuta sobre o vazio e a falta de sentido de tudo.

- Maria Célia Martirani, (São Paulo, 1959 - reside em Curitiba), com os contos de Para que as árvores não tombem de pé, em que "narra poemas e poetiza a narrativa" e que, trabalha com "o fabulesco a serviço de uma exaltação do dizer em suas amplas potencialidades". Começou a interessar-se pela língua italiana quando estudante do Colégio Dante Alighieri em São Paulo. Formou-se em Direito pela USP. Em seguida, mudou-se para Santa Catarina, onde permaneceu sete anos. Foi um tempo e um espaço que lhe conferiram muitas vivências que hoje apresenta em seus textos. Exerce o magistério na UFPR, leciona a língua e a literatura italianas. Ao lado dessas atividades profissionais, Maria Célia nunca deixa de lado o ofício de escrever. É já uma escritora consagrada nos meios literários da capital paranaense. Tem dois livros publicados: Recontando, de 1993, e Para que as árvores não tombem de pé-Affinché gli alberi non cadano in piedi, publicado, portanto, em edição bilíngue, português e italiano, em 2008.

- Paulo Sandrini (Vera Cruz-SP, 1971 - reside em Curitiba desde 1994), formou-se em design pela UFPR. Trabalhou com publicidade, tv e música - foi guitarra e voz da banda My Sweet Lord. Publicou de forma independente Vai ter que engolir (2001) e pela Travessa dos Editores os livros de contos $O$ estranho hábito de dormir em pé (2003) e Códice d'incríveis objetos \& Histórias de Lebensraum (2005). Atualmente, é designer gráfico e membro do conselho editorial da revista $E t$ Cetera.

- Assionara Souza (Caicó-RN, 1969 - reside em Curitiba), mergulha no delírio do experimento verbal, quebrando as barreiras do gênero. Publicou Cecília Não é um Cachimbo (Rio de Janeiro: 7Letras, 2005) e Amanhã com Sorvete (Rio de Janeiro: 7Letras, 2010). Faz parte de Dedo de moça - uma antologia das escritoras suicidas (São Paulo: Terracota Editora, 2009). Doutoranda em Estudos Literários (UFPR), pesquisa a obra de Osman Lins. Publica alguns de seus textos inéditos em livro no blogue Cecília Não É Um Cachimbo.

- Guido Viaro Neto (Curitiba, 1968), neto do pintor Guido Viaro, escreve ficção desde os 15 anos, pequenos textos, poesias, apontando o também acadêmico Paulo Venturelli, seu professor no colégio, como presença influente em suas primeiras tentativas literárias. Diz sempre ter tido o impulso e necessidade de falar de "um mundo interno que não combinava com o externo". Guido já escreveu e publicou onze romances entre eles $O$ quarto no universo e No zoológico de Berlim, um livro sobre um homem preso que, mesmo atrás das grades, luta para que sua alma não acompanhe 
seu corpo, e o último lançamento Confissões da condessa Beatriz de Dia, além de ter feito o roteiro e dirigido três filmes, os curta-metragem "Fui rei”, e "Maya", e o longa "O Quarto do Universo", baseado no seu primeiro romance, com o mesmo título. Recentemente, filmou o documentário "A vida de Jair", sobre o artista Jair Mendes, que está em fase de pós-produção. "O cinema - diz ele — sempre foi uma grande paixão, mas é uma arte difícil. Por isso escolhi a literatura”.

- Cezar Tridapalli (Curitiba, 1974), estudou Letras e também fez mestrado em Estudos Literários na UFPR. Tradutor da língua italiana, ensaísta e autor de contos esparsos, Pequena biografia de desejos é seu primeiro romance.

- Marcio Renato dos Santos (Curitiba, 1974), Mestre em Estudos Literários pela UFPR, é jornalista e atua na Biblioteca Pública do Paraná. Minda-Au é sua estreia na ficção (contos, lançado pela Record em 2010). O nome impronunciável do segundo livro de contos é uma resenha em si mesmo: Golegolegolegolegah!. Segundo o autor, o título impronunciável faz alusão à incomunicabilidade. "Estamos no século 21 e, apesar dos equipamentos, do avanço e da disponibilidade dos recursos tecnológicos, quase não conseguimos nos comunicar. Todos falam, ninguém se entende. É o caos. É a incomunicabilidade. É isso que está no livro", comenta. Golegolegolegolegah!, tem seis contos, sempre narrados em primeira pessoa.

- Luís Henrique Pellanda (Curitiba, 1973), é escritor, jornalista, dramaturgo, roteirista e músico. Coeditor e cronista do site de crônicas e ilustrações Vida Breve, é autor do livro de contos $O$ macaco ornamental. Formado em jornalismo pela Pontifícia Universidade Católica do Paraná, trabalhou nas redações dos jornais Gazeta do Povo e Primeira Hora e foi subeditor e colunista do jornal literário Rascunho. Publicou também Nós passaremos em branco, de crônicas, e é o responsável pela organização dos dois volumes das melhores entrevistas do Rascunho.

- Regina Benitez (1934-2006), falecida e jogada no ostracismo foi resgatada por Paulo Sandrini, que publicou Mulher com avestruz e A moça do corpo indiferente, contos em que a solidão da condição feminina é a têmpera primeira da escritora. Mulher com Avestruz reúne cerca de vinte contos que permaneciam inéditos, ainda que vários tenham sido premiados em diversos concursos. Os originais foram entregues por Greta Benitez, filha da autora, ao editor Paulo Sandrini, depois que ele manifestou interesse em resgatar a obra ficcional de Regina. "A ideia é valorizar grandes autores locais que tem suas obras pouco divulgadas”, explica Sandrini. A autora falecida em 2006 é, portanto, praticamente desconhecida da maioria dos leitores - ela é mais lembrada por sua atuação de décadas no jornalismo cultural de Curitiba e São Paulo. Regina escreve uma prosa incomum, 
com linguagem refinada que cria narrativas, por vezes, surreais. Suas personagens femininas vivem em um universo onírico e estranho, em que bonecas de chocolate falam e um sujeito se apaixona pela mulher que mandou tatuar em seu braço depois que esta ganha vida.

- Marcelo Sandmann (Curitiba, 1963), poeta, músico, professor de Literatura Portuguesa na Universidade Federal do Paraná. Publicou Lírico renitente (2000) e Criptográfo amador (2005). É um dos autores do poema do CD Cantos da Palavra (1998). Em seu último livro, Na franja dos dias, apresenta um trabalho poético extraordinário, impactante pela modernidade/contemporaneidade e pelo tráfego solto por temas corriqueiros ou metafísicos.

- Adriano Smaniotto (Curitiba, 1975), publicou os livros de poemas Arcano (Editora Ócios do Ofício, 1995); primeiro poeta a ser publicado na Coleçâo Sapatos Tortos (FCC, 1997); Regra de três (parceria com David Nadalini e Fernando Koproski (Editora Ocios do Ofício, 1998); Vinte vozes de uma mesma veia (Ed. do Autor, 1999) e Versejar a voz do ser é ser de si algoz (Fundação Cultural de Curitiba/Imprensa Oficial do Paraná, Curitiba, 2000).

- Carlos Dala Stella (Curitiba, 1961), escreveu O gato sem nome. Pintor e poeta, formado em Letras pela Universidade Federal do Paraná (1983), foi redator do jornal Nicolau, da Secretaria de Estado da Cultura do Paraná (1990), e mais recentemente colunista do caderno de cultura do jornal Gazeta do Povo. Desde 1987, vem se dedicando regularmente às artes plásticas.

- Maurício Arruda Mendonça (Londrina, 1964), é dramaturgo, poeta, tradutor e músico. Como poeta publicou os livros: Epigrafias (2002); A Sombra de um Sorriso (2002); Eu Caminhava Assim Tão Distraído (1997). Integrou as antologias poéticas Outras Praias/Other Shores (1998); Na Virada do Século - Poesia de Invenção no Brasil (2002); Passagens - Antologia de Poetas Contemporâneos do Paraná (2002). Como tradutor publicou, a antologia Trilha Forrada de Folhas - Nenpuku Sato, um Mestre de Haikai no Brasil, compilação e estudo inédito da obra do poeta japonês Nenpuku Sato, o introdutor do haikai no em nosso país (1999); Sylvia Plath, Poemas (1991) e Iluminuras (Gravuras Coloridas) tradução das Illuminations de Arthur Rimbaud (1994), os dois últimos títulos com Rodrigo Garcia Lopes. Em teatro traduziu Molière, Tennessee Williams, Samuel Beckett, Sam Shepard e Tracy Letts. Publicou em parceria com o diretor Paulo de Moraes os livros de dramaturgia: Antes da coisa toda começar/Antes del inicio de todo (2011); Inveja dos Anjos/Envy of Angels (2010); e Pequenos Milagres - texto do espetáculo comemorativo dos 25 anos do Grupo Galpão (2008). Em 2010 publicou Londrinenses, seu primeiro livro de contos. Em 2012 publicou o livro Quatro Comédias contendo dramaturgias de sua 
autoria solo. Como músico compôs canções para espetáculos teatrais como Marat/Sade (1998) e Antes da coisa toda começar (2010). Além de composições próprias, mantém parceria como letrista com o compositor Bernardo Pellegrini desde 1991, com canções gravadas nos CDs Dinamite Pura (1994) e É isto que vai acontecer (2009). É Mestre em Letras pela Universidade Estadual de Londrina tendo defendido dissertação sobre o romance experimental Catatau de Paulo Leminski. Atualmente cursa o doutorado em Letras daquela mesma instituição redigindo tese sobre Kafka e Schopenhauer.

Em 2012 seu monólogo O outro Van Gogh atuado por Fernando Eiras e dirigido por Paulo de Moraes foi considerado um dos 10 melhores espetáculos da temporada 2012 segundo o jornal O Globo. Em 2012 recebeu juntamente com Paulo de Moraes o Prêmio Shell-RJ de Melhor Autor pela peça A Marca da Água da Armazém Companhia de Teatro. Em 2013 recebeu juntamente com Paulo de Moraes o Prêmio Fringe First do Festival de Teatro de Edimburgo, Escócia, "for innovating and outstanding new writing" da peça A Marca da Água/Water Stain - prêmio inédito para o teatro brasileiro e para a dramaturgia em língua portuguesa.

- Luiz Felipe Leprevost (Curitiba, 1979), poeta, dramaturgo, contista, músico, ator e diretor teatral. Formado em Artes Cênicas pela Casa de Artes de Laranjeiras (CAL), no Rio de Janeiro. É autor do livro/CD "Fôlego" (2002, edição do autor) e dos livros "Tornozelos Deitados" (2005, Kafka Edições Baratas), "Cecília Roendo as Unhas" (2005, Kafka Edições Baratas), "Ode Mundana" (2006, Editora Medusa), "Pífio, monólogos dos psicotrópicos que não fazem mais efeito" (2007, Kafka Edições) e "Inverno dentro dos Tímpanos" (2008, Kafka Edições).

Em seus romances, os personagens de Leprevost vivem uma vida vazia de sentido e para cobrir este vazio, lá vem a droga, o álcool, a estupidez de um cotidiano sem projeto e sem guarda. Podres nesta vida, tais criaturas estão amortecidas pela padronização, robotizados em seus "sentimentos", são seres desindividualizados e emparedados por estruturas de alienação. Nada lhes salva e, na verdade, ninguém está preocupado em salvar- se desta não-vida, se contentando em rastejar pelo chão duro de uma realidade de quem não atingiu a rigor o nível da humanidade. A satisfação burra vem de um baseado, da cachaça, da cocaína, da pancada na cara do outro, pois assim encontram adrenalina e investidos por ela, pensam cobrir o buraco de seu dia a dia. O contista lança um agudo olhar sobre a Curitiba oficial. A Curitiba do Primeiro Mundo. A Curitiba como exemplo para outras cidades. A Curitiba para AS FAMÍLIAS. O autor desmonta estes mitos e 
vai fundo nas feridas sociais de uma cidade que tem o maior índice de drogados jovens, entre as capitais, segundo a fala de um candidato a prefeito nas últimas eleições. Leprevost mostra os cadáveres ambulantes. Não enfeita a janela pela qual vê o mundo e a cidade. Leprevost escreve de maneira solta, jovem, divertida, sem julgar nada, sem ser moralista.

A antologia de poetas contemporâneos do Paraná, Passagens, organizada por Ademir Demarchi e publicada em 2002 nos traz 26 poetas contemporâneos:

- Ademir Assunção (Araraquara, 1961 - atualmente reside em São Paulo mas residiu por mais de 10 anos em Londrina). Poeta, escritor, jornalista e letrista de música. Formou-se em jornalismo pela Universidade Estadual de Londrina, e trabalhou como repórter e editor nos jornais e revistas Folha de Londrina, O Estado de São Paulo, Jornal da Tarde e Folha de S. Paulo. Além disso, trabalhou como editor-contribuinte para a revista Marie Claire, como co-editor da revista literária K'an e participou de exposições de poesia visual na França, Austrália e Portugal. . É um dos editores da revista Coyote, junto com os poetas Marcos Losnak e Rodrigo Garcia Lopes. Como letrista, tem parcerias gravadas em discos com alguns artistas da música brasileira como Itamar Assumpção, Edvaldo Santana e Madan, e com as cantoras Maricene Costa, Patrícia Amaral e Titane. Tem poemas e contos em diversas antologias brasileiras e internacionais, publicadas na Argentina, México, Peru e EUA.

- Ademir Demarchi (Maringá, 1960). Nasceu em Maringá mas reside em Santos (SP), Doutor em Literatura Brasileira (USP), é editor de BABEL - Revista de Poesia, Tradução e Crítica. É autor de Os mortos na sala de jantar (Realejo Livros, 2007) e organizador de Passagens - Antologia de Poetas Contemporâneos do Paraná (Imprensa Oficial do Paraná, 2002). Tem poemas e ensaios.

- Adriano Smaniotto (Curitiba, 1975)

- Beto Carminatti (Rio das Onças-SC, 1961 - reside em Curitiba desde 1974)

- Edson de Vulcanis (Curitiba, 1957)

- Fernando Koproski (Curitiba, 1973) 
- Jairo B. Pereira (Passo Fundo-RS, 1956 - reside em Curitiba há mais de 20 anos)

- Josely Vianna Baptista (Curitiba, 1957)

- Jussara Salazar (Pernambuco, 1959 - reside em Curitiba desde 1985)

- Luci Collin (Curitiba, 1964)

- Maikon Kempinski (Curitiba, 1982)

- Marcelo Sadmann (Curitiba, 1963)

- Marco Aurélio Cremasco (Guaraci-PR, 1962)

- Marcos Losnak (Bauru-SP, 1964 - reside em Londrina há mais de 20 anos)

- Marcos Prado (Curitiba, 1961-1996)

- Marília Kubota (Paranaguá, 1964)

- Mario Bortolotto (Londrina, 1962)

- Mario Donadon Leal (São João do Caiuá-PR, 1963)

- Mauricio Arruda Mendonça (Londrina, 1964)

- Mauro Faccioni Filho (Maringá, 1962)

- Nivaldo Lopes (Itambaracá-PR, 1957)

- Ricardo Corona (Pato Branco-PR, 1962)

- Rodrigo Padro (Curitiba, 1959)

- Rodrigo Garcia Lopes (Londrina, 1965)

- Rollo de Rezende (Cambará-PR 1965-1995)

- Sabrina Bandeira Lopes (Curitiba, 1978)

Não participou dessa coletânea o escritor londrinense Alexandre Horner (1967-2013) que não manifestou interesse mas, é considerado pelo organizador como um nome de expressão na produção literária paranaense da contemporaneidade. 


\section{CONSIDERAÇÕES FINAIS}

A literatura elaborada por escritores do Paraná é muitas vezes criticada pela falta de identificação das obras com o povo, a geografia e a cultura paranaenses. Os críticos literários afirmam que os autores nascidos ou que realizaram boa parte de sua bibliografia nesse Estado apresentam textos com características de qualquer outra região do Brasil, menos com seu local de origem. Entretanto, enquanto alguns relatam que foi a literatura paranaense uma das primeiras a se envolver com o modernismo da década de 1920, outros destacam que esse movimento não encontrou representantes no Paraná, ou que chegou de maneira muito sutil, apenas 20 anos depois. Ainda na década de 1930 a literatura local era caracterizada como pertencente ao movimento do Simbolismo. Dez anos mais tarde, importantes autores do Estado foram responsáveis pela tentativa de modernização das formas e ideias na literatura paranaense, assim como a busca pela sua regionalização, em especial, Bento Munhoz da Rocha Neto e Dalton Trevisan, mas apesar da criação de um periódico de sucesso, a revista "O Joaquim", não obtiveram maiores sucessos em suas iniciativas. Aliás, "O Joaquim” é o principal destaque literário no Estado, lançada em abril de 1946, e direcionada à exposição livre de ideias e a atualização de modelos para a arte paranaense, a revista circulou até o final de 1948.

Segundo os críticos da literatura do Paraná, os autores possuem um amplo material para produção de uma obra de maior identificação com o Estado, citando como exemplo as diversas lendas existentes; o ambiente geográfico com seus pinheiros e campos gerais; os ciclos econômicos, como o do tropeirismo e o da erva-mate; e importantes acontecimentos históricos, como a Guerra do Contestado e a participação dos paranaenses na Revolução Federalista. Além disso, a própria figura do tropeiro poderia ser utilizada como a representação de um herói ou um modelo que identifique o povo do Estado para as outras regiões do país.

$\mathrm{Na}$ produção literária local encontram-se grandes nomes, muitos deles reconhecidos nacionalmente por suas obras. Da capital Curitiba vieram os escritores Paulo Leminski, poeta, tradutor, prosista, contista e compositor de várias músicas; Dalton Trevisan, contista que destaca-se pelo realismo e pela ligação de sua obra com sua cidade natal; Emiliano Perneta, simbolista considerado o Príncipe dos Poetas Paranaenses; Emilio de Menezes, poeta envolvido com o parnasianismo e o simbolismo; Andrade Muricy, historiador, crítico e músico e autor de diversos ensaios e obras de ficção; Tasso da Silveira, poeta modernista voltado à temática da religiosidade; e Alice Ruiz, autora e tradutora de haikais. 
Da região litorânea do Paraná saíram os simbolistas Nestor Vitor, autor de poesias, contos, romances e ensaios; e Silveira Neto, poeta com temas que revelam um certo pessimismo e também seu apego à família. Nos Campos Gerais, mais precisamente em Ponta Grossa, nasceu Noel Nascimento, um dos poucos autores considerados "paranistas" por incluir em suas obras partes da história e da geografia do Estado. Do sudeste paranaense, veio a poetisa cruz-machadense Helena Kolody, voltada aos haikais e a exaltação à natureza e a vida. Na nova geração de autores está o londrinense Domingos Pellegrini, autor de contos, romances e poesias com temáticas sociais.

Apesar de tão criticada, a literatura paranaense está se tornando cada vez mais presente por iniciativa de diversas entidades que promovem concursos literários, como os realizados em homenagem à Helena Kolody, Paulo Leminski e Newton Sampaio; e festivais, como o Festival Literário de Londrina - Londrix. Além disso, a produção local está em constante crescimento, assim como o espaço dedicado a ela nas salas de aula e bibliotecas distribuídas pelo Estado do Paraná.

Observamos que a literatura produzida no Paraná esteve sempre circunscrita a Curitiba, por ser capital e por estar integrada de forma sistêmica à vida nacional, enquanto que o interior do estado, de colonização incipiente, cujas maiores cidades tem poucas décadas de existência, somente começou a ter escritores muito recentemente. Tal fato pode ser comprovado pela antologia de Demarchi (2002) com praticamente metades dos 26 poetas sendo oriundos de Curitiba, uma parte oriunda de outros estados e boa parte do interior do estado, sinalizando uma mudança nesse cenário.

Existe uma produção literária no Paraná que pode ser considerada significativa, representada por uma tradição (se comprada com outros estados ainda muito pequena, mas que existe). A tradição paranaense circunscreve à produção dos simbolistas, com repercussão nacional (como Dario Veloso, Emílio de Menezes, Tasso da Silveira, Helena Kolody). Depois desses encontramos novos fluxos importantes numa geração mais recente como Paulo Leminski e Cristóvão Tezza, noutra como Wilson Bueno, chegando na relação de nomes da geração mais contemporânea que, produzindo entre o final do século XX e início do século XXI, ainda estão com sua obra em elaboração, aprofundando sua estética.

\section{REFERÊNCIAS}

ACADEMIA PARANAENSE DE LETRAS. Bibliografia Curitiba: Academia Paranaense de Letras, 2011. 
BEGA, Maria Tarcisa Silva. Letras e política no Paraná: Simbolistas e anticlericais na República Velha. Curitiba: Editora da UFPR, 2014.

BEGA, Maria Tarcisa Silva. Sonho e invenção do Paraná: geração simbolista e a construção de identidade regional. SP: Tese de Doutorado em Sociologia, USP, 2001.

BELTRAMI, RAFAEL C. DE C. DA POESIA NA CIÊNCIA Fundadores do Instituto Histórico e Geográfico do Paraná, uma história de suas ideias. Curitiba, 1900. Curitiba: Dissertação de Mestrado em Letras da UFPR, 2002.

BOSI, Alfredo. História concisa da literatura brasileira. $43^{\circ}$ edição. SP: Cultrix, 2006.

CENTRO Feminino de Cultura. Um século de poesia: poetisas do Paraná. Curitiba: Imprensa Oficial do Estado do Paraná, 1959.

COSTA, Maria José Franco Ferreira da. Lysímaco Ferreira da Costa. A Dimensão de Um Homem. Curitiba: UFPR, 1987.

DEMARCHI, Ademir. Passagens - Antologia de Poetas Contemporâneos do Paraná. Curitiba: Imprensa Oficial do PR, 2002.

IORIO, Regina Elena Saboia. Intrigas e Novellas - literatos e literatura em Curitiba na década de 1920. Curitiba: Tese Doutorado em História da UFPR, 2003.

JÚNIOR, Nascimento. Júlia da Costa. Conferência. Paranaguá, p. 04-16, 01 de jul. 1944

LIMA, Rosy Pinheiro. Vida de Júlia da Costa. Curitiba. Escola Técnica de Curitiba, 1953.

MELLO, Silvia Gomes de. Esses moços do Paraná... Livre circulação da palavra nos albores da República. Florianópolis: Tese de Doutorado em História, 2008.

MENEZES, Raimundo de. Dicionário literário brasileiro - $2^{\text {a }}$ edição. Rio de Janeiro, Livros Técnicos e Científicos, 1978.

MURICY, José Candido de A. Panorama do Conto Paranaense. Curitiba: Fundação Cultural de Curitiba, 1979.

MURICY, Andrade. Panorama do Movimento Simbolista Brasileiro. RJ: Imprensa Nacional, 1952.

MUZART, Zahid Lupinacci. Anuário de Literatura. São Paulo: Companhia de Letras, 1987.

MYSKIW, A. M. . Curitiba República das letras. Revista eletrônica história em reflexão (UFGD), v. 2, p. 1, 2008.

REBINSKI JUNIOR, Luiz. Um outsider na Província: Newton Sampaio. Curitiba: Jornal Candido, setembro de 2013.

ROCHA NETTO, Bento Munhoz da. "Da necessidade de divulgação da História Paranaense". IN: WESTPHALEN, C. História do Paraná, volume 1. Curitiba: GRAFIPAR, 1969, p. 11-23

RODRIGO JR., e PLAISANT, Alcibiades. Antologia paranaense. Tomo primeiro (poesia). Curitiba: Ed. Livraria Mundial. 1938. 
SANTOS, Marcio Renato dos. Brejos das Almas: o intelectual na ficção de Newton Sampaio. Curitiba: Dissertação Mestrado em Letras UFPR, 2005.

SILVA, Inocêncio Francisco da. Dicionário Bibliográfico. Lisboa: Imprensa Nacional, 1927.

SILVEIRA, Allan Valenza da. Diálogos críticos de Nestor Vítor. Curitiba: Tese de Doutorado em Letras UFPR, 2005.

SYDOR, Adriana (org). Livro dos novos. Curitiba: Travessa dos Editores, 2013.

VENTURELLI, Paulo. "A literatura paranaense". IN: CANDIDO (Jornal da Biblioteca Pública do Paraná), N.25, agosto de 2013.

\section{A walk through the Paranaense literature}

\section{ABSTRACT}

This paper aims to point out the different authors that marked the Paraná literature. It is an incomplete character of work and absolutely exploratory, because just point the Parana writers and not deal with the debates and issues placed in question by them. You can consider this work a kind of foray into uncharted territory. Raid that marked by the fact that when asked about the Paranaense literature does not have a lot to answer at the time. Despite having a literature widely criticized for the lack of identification of works produced with the territory and the culture of Paraná, Paraná is recognized for having revealed great authors to the scene of the national literature. Here are some of the most established names in Paraná literature, recognized not only for their readers, but also by critics and by great writers.

Keywords: Paranaense Literature. literary currents. Literature and politics. 


\section{ANEXOS}

CENTRO DE LETRAS DO PARANÁ: fundado em 1912

ACADEMIA DE LETRAS DO PARANÁ: fundada em 1922

Nasce de um movimento no interior do Centro de Letras do Paraná, de onde se retiram Rocha Pombo, Silveira Netto, Romário Martins, Santa Ritta, Serafim França, Andrade Muricy, Nestor Vitor, Leôncio Correia e Tasso da Silveira.

ACADEMIA PARANAENSE DE LETRAS: fundada em 1936

É a fusão do Centro de Letras do Paraná com os remanescentes da Academia de Letras do Paraná.

\section{CENTRO DE LETRAS DO PARANÁ}

Fundado em 19 de dezembro de 1912 no salão de honra do jornal Diário da Tarde, com o obejtivo de enaltecer os valores da criatividade literária, poética e musical paranaenses. Foram seus sócios fundadores, Euclides Bandeira e Emiliano Perneta. Atualmente está localizado na Rua Fernando Moreira, 370 em Curitiba.

Presidentes

1912-1913: Euclides Bandeira

1913-1918: Emiliano Perneta

1918-1921: Pamphilo D’Assumpção

1921-1922: José Henrique de Santa Rita

1922 : Jayme Ballão

1922-1934: Pamphilo D’Assumpção

1934-1940: Ulysses Falcão Vieira

1940-1944: Octávio de Sá Barreto

1944-1947: Breno Arruda

1947-1948: Rodrigo Júnior

1948-1949: Gláucio Bandeira

1949-1952: Leonor Castellano 
1952-1954: David S. Carneiro

1954-1956: Laertes de Machado Munhoz

1956-1958: Gláucio Bandeira

1958-1960: Heitor Stockler de França

1960-1961: Júlio Estrela Moreira

1961-1964: Vasco José Taborda Ribas

1964-1966: Gláucio Bandeira

1966-1968: Vasco José Taborda Ribas

1968-1970: Juril Carnasciali

1970-1972: Luiz Piloto

1972-1974: Benedito Nicolau dos Santos

1974-1976: Ário Taborda Dergint

1976-1978: Leopoldo Scherner

1978-1980: Vasco José Taborda Ribas

1980-1982: Apollo Taborda França

1982-1985: Vasco José Taborda Ribas

1985-1987: Harley Clóvis Stocchero

1987-1989: Felício Raitani Neto

1989-1991: Valfrido Piloto

1991-1993: Lauro Grein Filho

1993-1995: Samuel Guimarães da Costa

1995-1997: Fernandino Caldeira de Andrada

1997-1999: Adélia Maria Woellner

1999-2001: Luís Renato Pedroso

2001-2003: Luís Renato Pedroso

2003-2005: Luís Renato Pedroso

2005-2007: Luís Renato Pedroso

2008-2010: Luís Renato Pedroso

2010-2012: Luís Renato Pedroso 
FONTE: http://centrodeletrasdoparana.blogspot.com.br/. Acesso em 30 de janeiro de 2014.

\section{ACADEMIA PARAENSE DE LETRAS}

A Academia Paranaense de Letras foi fundada em Curitiba, em 26 de setembro de 1936, sucedendo a antiga Academia de Letras do Paraná, criada em 1922 e dissolvida por motivos políticos. A recriação de uma entidade cultural representativa da cultura do Estado, deu-se por estímulo e influência da Academia Carioca de Letras e da Federação das Academias de Letras do Brasil. Exerceu a liderança, nesse propósito, o Professor Dr. Ulysses Vieira que reagrupou intelectuais dispostos a resgatar os valores acadêmicos dispersos por força das velhas dissidências.

Da extinta Academia de Letras, alinharam-se na promoção da nova instituição nascente, figuras de relevo, tais como Dom Alberto José Gonçalves, João Cândido, Sebastião Paraná, Dario Velozzo, Santa Rita, Leônidas Loyola, Pamphilo d'Assupção, Silveira Neto, Tasso da Silveira, Andrade Muricy, Leôncio Correia, Lacerda Pinto, Azevedo Macedo e Romario Martins. As cadeiras restantes foram ocupadas por outros intelectuais, totalizando quarenta.

A primeira diretoria foi constituída de:

Presidente: Ulysses Falcão Vieira

Vice-Presidente: Francisco Leite

Secretário Geral: De Sá Barreto

$1^{\circ}$ Secretário: Benedito Nicolau dos Santos

$2^{\circ}$ Secretário: Ciro Silva

Tesoureiro: Pereira de Macedo

Bibliotecário: Valfrido Piloto

\section{Presidentes:}

1936 -1942: Ulysses Falcão Vieira

1943 - 1955: Oscar Martins Gomes

1956 - 1957: De Sá Barreto

1958 - 1966: Oscar Martins Gomes

1967 - 1970: Osvaldo Piloto

1970 - 1990: Vasco Taborda Riba

1991 - 1992: Felício Raitani Neto

1993 - 1994: Valfrido Piloto 
1995 - 2008: Túlio Vargas

2009 - 2011: José Carlos Veiga Lopes (falece quase no fim do manda e assume a vice-presidente, Chloris Casagrande Justen, a primeira mulher a dirigir a APL)

2012 - 2013: Eduardo Rocha Virmond

2013: Chloris Casagrande Justen

FONTE: http://www.academiapr.org.br/. Acesso em 30 de janeiro de 2014. 